DOI: $10.24850 / j-t y c a-2021-03-08$

Articles

\title{
Bioadsorption of methyl orange and methylene blue contained in water using as bioadsorbent natural brushite (nDCPD)
}

\section{Bioadsorción de naranja de metilo y azul de metileno contenidos en agua usando brushita natural (nDCPD) como bioadsorbente}

Estefania Joaquín-Medina1, ORCID: http://orcid.org/0000-0002-86248300

Laura Patiño-Saldivar², ORCID: http://orcid.org/0000-0002-5293-453X

Alba A. Ardilas A. ${ }^{3}$, ORCID: http://orcid.org/0000-0002-7675-0647

Mercedes Salazar-Hernández ${ }^{4}$, ORCID: http://orcid.org/0000-00018039-8124

José A. Hernández5, ORCID: http://orcid.org/0000-0002-0584-3715

${ }^{1}$ Instituto Politécnico Nacional, UPIIG, Silao de la Victoria, Guanajuato, Mexico, brambila796@gmail.com

2Instituto Politécnico Nacional, UPIIG, Silao de la Victoria, Guanajuato, Mexico,patinio2103@gmail.com 


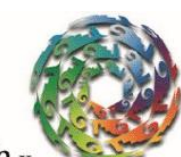

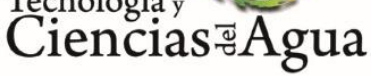

2021, Instituto Mexicano de Tecnología del Agua

Open Access bajo la licencia CC BY-NC-SA 4.0

(https://creativecommons.org/licenses/by-nc-sa/4.0/)

3Politécnico Colombiano Jaime Isaza Cadavid, Medellín, Colombia, anardila@elpoli.edu.co

4Departamento de Ingeniería en Minas, Metalurgia y Geología, Universidad de Guanajuato, Guanajuato, Mexico, merce@ugto.mx

5Instituto Politécnico Nacional, UPIIG, Silao de la Victoria, Guanajuato, Mexico, jahernandezma@ipn.mx

Corresponding author: José A. Hernández, jahernandezma@ipn.mx

\begin{abstract}
Textile industry contributes significantly to dyes water pollution like methylene blue (MB) and methyl orange (MO). In this study the equilibrium adsorption of $\mathrm{MB}$ and $\mathrm{MO}$ present in the water was investigated using nDCPD as bioadsorbent, an eco-economic and environmentally friendly material. The data isotherms showed the best fit for the Freundlich model with dyes, having the high adsorption capacity at $45{ }^{\circ} \mathrm{C}(179.84 \mathrm{mg} / \mathrm{g})$ and $25{ }^{\circ} \mathrm{C}(165.6 \mathrm{mg} / \mathrm{g})$ for $\mathrm{MB}$ and $\mathrm{MO}$, respectively. Thermodynamic studies reveal that adsorption is a spontaneous and irreversible process for both dyes, however, for MB, the adsorption is endothermic, and $M O$ is exothermic. Kinetics studies displays that the MB adsorption follows a pseudo second order kinetics $\left(125.1 \mathrm{mg} / \mathrm{g}\right.$ at $\left.25^{\circ} \mathrm{C}\right)$ while $\mathrm{MO}\left(193.3 \mathrm{mg} / \mathrm{g}\right.$ at $\left.45^{\circ} \mathrm{C}\right)$ follow a kinetic of pseudo first order. It can be specified that nDCPD has a great affinity for removal of both dyes so this material can be used for water treatment at low cost.
\end{abstract}




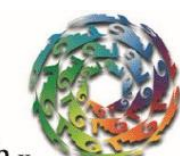

Ciencias: ־ Agua
2021, Instituto Mexicano de Tecnología del Agua

Open Access bajo la licencia CC BY-NC-SA 4.0

(https://creativecommons.org/licenses/by-nc-sa/4.0/)

Keywords: Bioadsorption, kinetics, isotherm, nDCPD, thermodynamic, bioadsorbent.

\section{Resumen}

La industria textil contribuye de modo significativo a la contaminación del agua con colorantes, principalmente en sus efluentes, que contienen diferentes colorantes, en especial azul de metileno (MB) y naranja de metilo (MO). En este estudio se investigó la adsorción en equilibrio de MB y MO presentes en el agua utilizando nDCPD como bioadsorbente, un material eco-económico y ecológico. Los datos experimentales de equilibrio seleccionados se ajustan con las isotermas especificadas en la literatura; dan el mejor ajuste con Freundlich en ambos tintes y se tiene la mejor capacidad de adsorción a $45^{\circ} \mathrm{C}(179.84 \mathrm{mg} / \mathrm{g})$ y $25^{\circ} \mathrm{C}(165.6$ $\mathrm{mg} / \mathrm{g}$ ) para MB y MO, respectivamente. El análisis termodinámico nos dice que la adsorción es un proceso espontáneo e irreversible para ambos tintes; sin embargo, para MB, la eliminación es endotérmica y MO es exotérmica. La cinética del bioadsorbente con los colorantes indica que sigue una cinética de pseudo segundo orden para MB $(125.1 \mathrm{mg} / \mathrm{g}$ a 25 $\left.{ }^{\circ} \mathrm{C}\right)$, mientras que para $\mathrm{MO}\left(193.3 \mathrm{mg} / \mathrm{g}\right.$ a $45{ }^{\circ} \mathrm{C}$ ) es de orden pseudoprimero. Se puede especificar que el nDCPD tiene afinidad por ambos colorantes, por lo que este material puede ser específico para su uso en el tratamiento del agua a bajo costo.

Palabras clave: bioadsorción, cinética, isoterma, nDCPD, termodinámica, bioadsorbente.

Received: 22/04/2020 
Tecnología y

Ciencias $\stackrel{\Xi}{\approx}$ Aua
2021, Instituto Mexicano de Tecnología del Agua

Open Access bajo la licencia CC BY-NC-SA 4.0

(https://creativecommons.org/licenses/by-nc-sa/4.0/)

Accepted: $23 / 08 / 2020$

\section{Introduction}

In recent years has been paid to climate change due to pollution produced by human activity what has led to drastic measures on environmental regulations, especially concerning to drinking water which is a resource that is becoming scarcer (Bulgariu et al., 2019; Holkar, Jadhav, Pinjari, Mahamuni, \& Pandit, 2019; Kyzas, Bikiaris, \& Mitropoulos, 2017; Li, Wang, Guo, Li, \& Shuai, 2017). Governments seek a responsible use of water by the industries such as ceramics, clothing, photography, paintings, and others such as food, pharmaceutical, textile, etc. (Pargoletti et al., 2019; Holkar et al., 2019; Pavithra, Kumar, Jaikumar, \& Rajan, 2019; Kwak, Hong, Lee, \& Jin, 2018). These industries use both synthetic and vegetable dyes for skin processing and prints, etc., however, after the dying process, around $80 \%$ of these dyes lose remain in the dye bath making coloured effluent (Panneerselvam, Arul, Warrier, Asokan, \& Dong, 2019), which is discharged into the drain along with wastewater where most cases have no treatment which causes great pollution in lakes and rivers that are the main source of drinking water for the population. 
Dyes are toxic compounds and can harm aquatic animals (Bhatia, Sharma, Singh, \& Kanwar, 2017; Guo, Li, Liu, \& Lv, 2014; Zhang, Wua, $\&$ Cha, 2019). Moreover, they can prevent light from being in contact with plants causing photosynthesis and other biochemical processes to be directly affected can lead to the decreased oxygen concentration in water (Bulgariu et al., 2019; Kwak et al., 2018; Guo et al., 2014; Zhou, Lu, Zhou, \& Liu, 2019; Wang, Zhou, Jiang, \& Sun, 2008). In the case of methylene blue (MB) particles have an aromatic heterocyclic structure and is a cationic dye, it can have serious consequences for human living beings whether contact or intake can cause headache, gastritis, diarrhea among other diseases related to the digestive system (Nayak \& Pal, 2017; Altintig, Altundag, Tuzen, \& Sari, 2017).

In addition, to having a significant impact on the flora and fauna (Guo et al., 2014). While Methyl Orange (MO) has also an aromatic structure but is an anionic dye, it is usually used in the dyeing of the textile industry but possesses mutagenic properties which can cause serious damage by causing chronic degenerative diseases (Uddin \& Baig, 2019; Srilakshmi \& Saraf, 2016). Several methods have been proposed for the treatment of textile industry wastewater contaminated with different dyes, among them coagulation, ozonation, use of membranes, electrocoagulation, biological treatments, adsorption with activated carbon and nanomaterials, etc. (Holkar et al., 2019; Pavithra et al., 2019; Cai et al., 2017; Zhou et al., 2019; Meksi \& Moussa, 2017; Ma, Zheng, Mo, Dong, \& Qiu, 2018; Sivakumar, Murugesan, Loganathan, \& Sivakumar, 2014; Cao, Pan, Shi, \& Yu, 2018). They are usually very efficient processes but are very expensive and present great difficulty for their implementation in scale industry. To try to reduce the operating costs for the treatment 


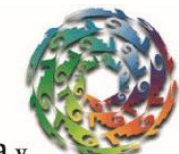

Ciencias $₫$ Agua
2021, Instituto Mexicano de Tecnología del Agua

Open Access bajo la licencia CC BY-NC-SA 4.0

(https://creativecommons.org/licenses/by-nc-sa/4.0/)

of waste produced by these industries, such as meat and juice processing, the waste generated by these same industries to obtain bioadsorbents has been considered. Encouraging results have been obtained to try to eliminate the greatest amount of dye present in these waste waters (Zhou et al., 2019; Hernández-Maldonado, Torres-García, Salazar-Hernández, \& Hernández-Soto, 2017) because it has been shown to have a very low cost and due to its versatility it is a viable option for use in this type of problem.

In the particular case of the use of apatits, which have been shown to have properties for adsorption of metals such as $\mathrm{Cu}, \mathrm{Cd}$ and $\mathrm{Co}$ among others (Panneerselvam et al., 2019; Hernández-Maldonado et al., 2017). Additionally, it has also been used for the removal of dyes such as congo red, blue acid and yellow 4 (Adeogun et al., 2018; Varaprasad et al., 2018; Liu et al., 2019; Abdullah et al., 2019). Good results have been obtained in the adsorption of these dyes and other contaminants with hydroxyapatite (Hernández-Maldonado et al., 2017). Brushite (DCPD) is another apatite that also has a great interest in tissue engineering because it is used for the manufacture of "bone cement" mainly due to its great biocompatibility with bones (Schamel, Barrelet, Groll, \& Gbureck, 2017). In addition, DCPD has been used in the hidrocalomite removal presented good efficiency for the adsorption of this mineral. This apatite has also been used to remove $\mathrm{Cu}(\mathrm{II}), \mathrm{F}$ and $\mathrm{Pb}$ (II) ions where it has obtained a high adsorption capacity and high removal (>90\%) due to the phosphate groups present on the surface of nDCPD that participate in the process of removing these contaminants (Doan, Dung-Tran, Nzihou, \& Sharrock, 2014; Yang et al., 2019; Hernández-Maldonado et al., 2017; El-Hamidi, Mulongo-Masamba, Khachani, Halim, \& Arsalane, 2015). 


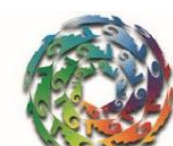

Ciencias
2021, Instituto Mexicano de Tecnología del Agua

Open Access bajo la licencia CC BY-NC-SA 4.0

(https://creativecommons.org/licenses/by-nc-sa/4.0/)

In this work, the removal of $M B$ and $M O$ present in an ideal solution was carried out using Brushite (nDCPD) obtained from beef bone. Several bioadsorption aspects were studied such as kinetic and thermodynamic process under different adsorption conditions (adsorption temperature and amount of bioadsorbent). This, in order to have a better understanding the MB and MO dyes adsorption on this type of materials.

\section{Materials and methods}

\section{Chemicals}

All chemicals used were analytical grade and for the solutions preparation the deionized water was used. The methylene blue (Sigma Aldrich, CAS: 122965-43-9), Figure 1a (MB, $\lambda_{\max }=662 \mathrm{~nm}$ ) and methyl orange (Sigma Aldrich, CAS: 547-58-0), figure $1 \mathrm{~b}\left(\mathrm{MO}, \lambda_{\max }=463 \mathrm{~nm}\right)$ dyes were used without any additional purification (Tamimi, Sheikh, \& Barralet, 2012; Farroq, Kozinski, Khan, \& Athar, 2010; Hernández-Soto, Hernández, Ardila-Arias, Salazar-Hernández, \& Salazar-Hernandez, 2019). 

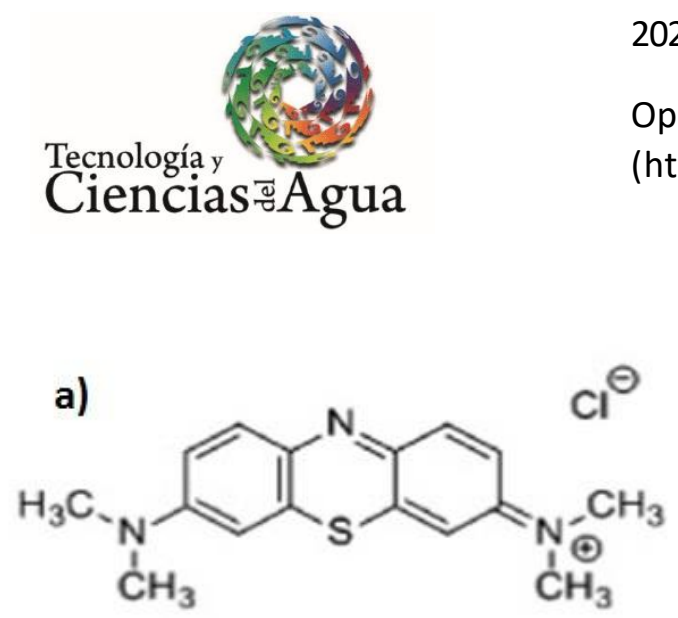

2021, Instituto Mexicano de Tecnología del Agua

Open Access bajo la licencia CC BY-NC-SA 4.0

(https://creativecommons.org/licenses/by-nc-sa/4.0/)

Figure 1. Color molecules MB and MO (Srilakshmi \& Saraf, 2016).

\section{Bioadsorbent preparation}

Natural Brushite (nCDCP) was obtained from the bovine bone which was washed with hot water and subsequently dried at $80^{\circ} \mathrm{C}$ by $24 \mathrm{~h}$. Subsequently, the bones were crushed and sifted to obtain a particle size of 150 mesh $(104 \mu \mathrm{m})$. The powder was treated with a solution of $\mathrm{HCl}$ (Baker, $35 \%$ ) and $\mathrm{NaOH}$ (Baker, $98 \%$ ), both at $10^{-2} \mathrm{M}$. It was eventually stored until use (Tamimi et al., 2012; Hernández-Soto et al., 2019).

\section{Natural brushite characterization}




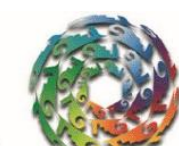

Ciencias $\approx$ Agua
2021, Instituto Mexicano de Tecnología del Agua

Open Access bajo la licencia CC BY-NC-SA 4.0

(https://creativecommons.org/licenses/by-nc-sa/4.0/)

Fourier's Transform infrared (FTIR) studies of samples were performed in an IR spectrophotometer (Nicolet iS10 Thermo Scientific), in a range of 4 000 to $400 \mathrm{~cm}^{-1}$ (Hernández-Soto et al., 2019). The Scanning Electron Microscopy (SEM) images were obtained in a JOEL (6510 plus). The textural properties of nDCPD were determined by a BET parser (Micromeritics ASAP, 2020 plus).

\section{Adsorption isotherm studies}

Different isotherm models were used to describe the adsorption of MB and MO proceeded as follows: $0.05 \mathrm{~g}$ of bioadsorbent was contacted with 50 $\mathrm{mL}$ of $\mathrm{MO}$ solution varying the concentration between 0 to $50 \mathrm{ppm}$ and for MB the concentration variation was 0 to $40 \mathrm{mg} / \mathrm{l}$, in a shaker (ZHWY200D) with a stirring of $200 \mathrm{rpm}$ at different temperatures (25, 35 and 45 ${ }^{\circ} \mathrm{C}$ ) by $24 \mathrm{~h}$ of contact time. The different models and equations of isotherms are present in Table 1.

Table 1. Non-linear adsorption isotherm models (Hernández-Maldonado et al., 2017; Hernández-Soto et al., 2019).

\begin{tabular}{|c|c|}
\hline Isotherm model & Equation \\
\hline Langmuir & $q_{e}=\frac{q_{m} K_{L} C_{e}}{1+K_{L} C_{e}}$ \\
\hline
\end{tabular}


Tecnología y

Ciencias $₫$ Agua
2021, Instituto Mexicano de Tecnología del Agua

Open Access bajo la licencia CC BY-NC-SA 4.0

(https://creativecommons.org/licenses/by-nc-sa/4.0/)

\begin{tabular}{|c|c|}
\hline Temkin & $q_{e}=A+B \ln \left(C_{e}\right)$ \\
\hline Freundlich & $q_{e}=K_{F} C_{e}^{\frac{1}{n}}$ \\
\hline $\begin{array}{c}\text { Dubinin-Radushkevich } \\
\text { (DR) }\end{array}$ & $q_{e}=q_{m} \exp \left(-k_{D R} \varepsilon^{2}\right)$ \\
\hline SIPS & $q_{e}=\frac{q_{m}\left(K_{s} C_{e}\right)^{\beta}}{1+\left(K_{S} C_{e}\right)^{\beta}}$ \\
\hline Redlich-Peterson & $q_{e}=\frac{K_{R} C_{e}}{1+a_{R} C_{e}^{n_{R P}}}$ \\
\hline (RP) & \\
\hline
\end{tabular}

where $q_{e}$ is the adsorption capacity $(\mathrm{mg} / \mathrm{g}) ; C_{e}$ is the dye concentration used $(\mathrm{mg} / \mathrm{l}) ; q_{m}$ is the maximum adsorbed capacity $(\mathrm{mg} / \mathrm{g}) ; K_{S}$ is the slaving sips model constant related to adsorption energy; $\beta$ is the dimensional parameter of the SIPS; $n_{R P}(0<n<1) ; K_{R}(\mathrm{mg} / \mathrm{g}(\mathrm{l} / \mathrm{mg}))$, and $a_{R}$ are the constants of the $R-P$ model; $K_{L}$ is the constant of the Langmuir model that is related to the separation factor $\left(R_{L}\right) ; A$ and $B$ are constant from the Temkin model; $K_{F}$ is the Freundlich constant related to adsorption capacity and $1 / n$ indicates adsorption energy; Temkin: $A$ $(\mathrm{l} / \mathrm{mg}), B(\mathrm{~kJ} / \mathrm{mol}) ; K_{D R}(\mathrm{~mol} / \mathrm{J})^{2}$ is the speed constant, and $\varepsilon(\mathrm{J} / \mathrm{mol})$ is the parameter of the DR model $\left(\varepsilon=R T \ln \left(1+\frac{1}{C_{e}}\right)\right)$. The regression coefficient was calculated to evaluate the fit of each nonlinear model and the separation factor, $R L$, which allows predicting the affinity between the bioadsorbent and adsorbate, using Equation (1) (Tamimi et al., 2012; Farroq et al., 2010; Hernández-Soto et al., 2019): 
$R_{L}=\frac{1}{1+K_{L} C_{0}}$

where $K_{L}(\mathrm{I} / \mathrm{mg})$ is the constant of the Langmuir model and $C_{0}$ is the initial concentration of MB or MO. To understand the thermodynamics of the adsorption process, thermodynamic parameters such as apparent Gibbs free energy were determined using the Equation (2):

$$
\Delta G=-R T \ln (k)
$$

Where:

$$
k=55.5 K_{L}
$$

where $R$ the ideal gas constant and $T$ is the absolute temperature $(K)$.

$$
\ln (k)=-\frac{\Delta H}{R T}+\frac{\Delta S}{R}
$$

The values of $\Delta H$ and $\Delta S$ can be determined with the slope and sorted to the origin of the $\ln (\mathrm{k})$ graphic as a function of $T^{-1}$. 


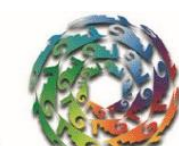

Ciencias $\stackrel{\sim}{\simeq}$ Agua

\section{Batch removal kinetics}

Kinetics removal experiments of the dyes in nDCPD were carried out in a reactor batch to know the development of $M O$ and $M B$ adsorption in the biomaterial. It was carried out by varying the concentration of $\mathrm{nDCPD}$ ( $C_{\text {ads }}$ ) from 0 to $20 \mathrm{~g} / \mathrm{l}$ for $8 \mathrm{~h}$ at a speed of $200 \mathrm{rpm}$ at different temperatures. At specific times, aliquots were taken and then were centrifuged (Hermie Labortechnik $\mathrm{GmbH}$ ) at $6000 \mathrm{rpm}$ by $10 \mathrm{~min}$ at 25 ${ }^{\circ} \mathrm{C}$. They were analyzed to know the concentration of the different dyes present in the solution by spectrophotometry (JENWAY 6705). The amount of dye removed by $\mathrm{nDCPD}$, q, was obtained using the Equation (5) (Hernández-Maldonado et al., 2017; Pakshiranja, Worku, Acheampong, Lubberding, \& Lens, 2013):

$q=\frac{V\left(C_{0}-C\right)}{m}$

where $C_{0}$ and $C$ is the initial concentration and at time $t$ or in equilibrium $(\mathrm{mg} / \mathrm{l}) ; V$ is the volume of solution $(\mathrm{I})$, and $m$ is the mass of $\operatorname{nDCPD}(\mathrm{g})$. The removal percentage, $\% R$, was calculated using the Equation (6) (Singh, Hasan, Talat, Singh, \& Gangwar, 2009):

$\% R=\frac{\left(C_{0}-C\right)}{C_{0}} * 100$ 
Experimental data were adjusted with the adsorption kinetics models described in Table 2.

Table 2. Kinetic models used for the analysis of experimental data for the adsorption of contaminants (Hernández-Soto et al., 2019).

\begin{tabular}{|c|c|}
\hline Kinetic models & Equation \\
\hline Pseudofirst order (PFO) & $q_{t}=q_{\max }\left[1-\exp \left(-k_{1} t\right)\right]$ \\
\hline $\begin{array}{l}\text { Pseudosecond order } \\
\text { (PSO) }\end{array}$ & $q_{t}=\frac{t}{\frac{1}{k_{2} * q_{\max }^{2}}+\frac{t}{q_{\max }}}$ \\
\hline Elovich & $q_{t}=\frac{1}{\beta}[\ln (t)+\ln (\alpha * \beta)]$ \\
\hline $\begin{array}{l}\text { Intraparticle diffusion } \\
\text { (ID) }\end{array}$ & $q_{t}=k_{\text {Int }} t^{0.5}$ \\
\hline $\begin{array}{c}\text { External diffusion } \\
\text { (ED) }\end{array}$ & $q_{t}=\frac{C_{0 *} V}{m}\left[1-\exp \left(-k_{\text {ext }} * t\right)\right]$ \\
\hline
\end{tabular}

where $q_{t}$ is the adsorption capacity $(\mathrm{mg} / \mathrm{g}) . \mathrm{C}_{0}$ is the initial concentration of the dye in the liquid $(\mathrm{mg} / \mathrm{l})$. $q_{\max }$, is the maximum adsorbed capacity $(\mathrm{mg} / \mathrm{g}) . k_{1}\left(\mathrm{~h}^{-1}\right)$ is the speed constant of the PFO model. $k_{2}(\mathrm{~g} / \mathrm{h} \mathrm{mg})$ is the speed constant of the PSO model. $k_{I n t}(\mathrm{mg} / \mathrm{g} \mathrm{h})$ is the speed constant of the ID model. $k_{E x t}\left(\mathrm{~h}^{-1}\right)$ is the speed constant of the model ED. $V(L)$ is the volume of the dye solution and $\mathrm{m}(\mathrm{g})$, is the mass of the bioadsorbent. 
In addition to using the coefficient of determination to compare the efficiency of the different kinetic and equilibrium models, the standard deviation, $\Delta \mathrm{q}$, was calculated using the Equation (7) (Wang, Chen, Wang, Feng, \& Yan, 2019):

$\Delta q=100 * \sqrt{\frac{\left(\frac{q_{\exp }-q_{c a l}}{q_{\exp }}\right)^{2}}{N-1}}$

where $N$ is the number of data, $q_{\exp }$ and $q_{\mathrm{cal}}(\mathrm{mg} / \mathrm{g})$ are the experimental and calculated values of the removed dyes, respectively.

\section{Results and discussion}

\section{Study in balance}

Figure 2 and Figure 3 show the adjustment of the experimental data with the different isotherm models for $M O$ and MB, respectively, at different temperatures. 
Tecnología y

\section{Ciencias $\stackrel{\Xi}{\Im}$ Agua}

2021, Instituto Mexicano de Tecnología del Agua

Open Access bajo la licencia CC BY-NC-SA 4.0

(https://creativecommons.org/licenses/by-nc-sa/4.0/)
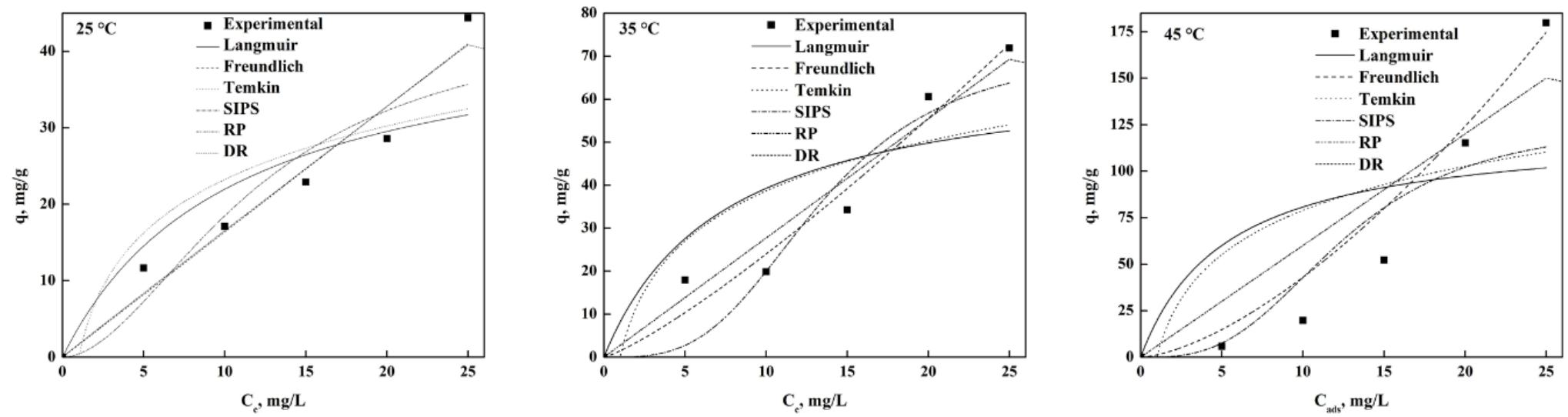

Figure 2. MB equilibrium adsorption capacity using nDCPD at different temperatures.
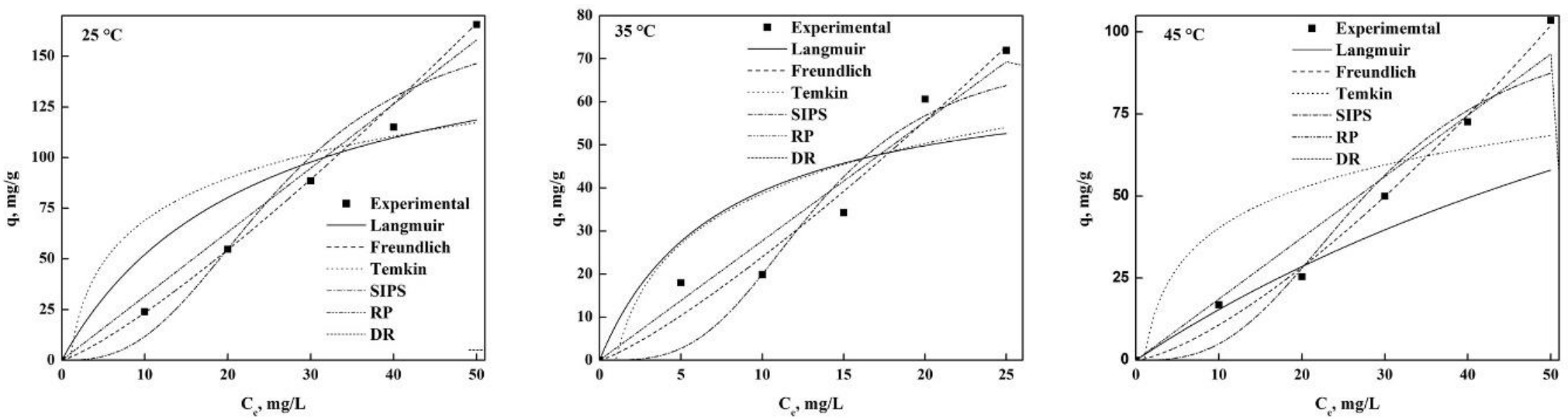

Figure 3. MO equilibrium adsorption capacity using nDCPD at different temperatures.

Table 3 shows the MB and MO parameters obtained from the settings of each isotherm type where it can observe that the models of SIPS, Langmuir and Freundlich revealed the better fit but based on the 


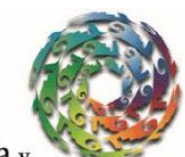

Ciencias $₫$ Agua
2021, Instituto Mexicano de Tecnología del Agua

Open Access bajo la licencia CC BY-NC-SA 4.0

(https://creativecommons.org/licenses/by-nc-sa/4.0/)

coefficient of determination $\left(R^{2}\right)$ and the standard deviation $(\Delta q)$, the Freundlich model is the most suitable for both dyes. This main that the balance is carried out without limitations of the formation of the monolayer and surface of nDCPD is highly heterogeneous allowing to have different adsorption heats scattered throughout the surface making it more efficient to remove the dyes. This result is consistent with the reported in the literature for different bioadsorbents (Kyzas et al., 2017; Kwak et al., 2018; Guo et al., 2014; Zhang et al., 2019; Uddin \& Baig, 2019; Cao et al., 2018; Rahman, Akter, \& Abedin, 2013; Do-Nascimiento et al., 2014; Tabrizi \& Yavari, 2015; Uyar, Kaygusuz, \& Erim, 2016; Li et al., 2016; Zong, Li, Tian, Lin, \& Lu, 2018; Mudyawabikwa, Mungondori, Tichagwa, \& Katwire, 2017; Cheng et al., 2015; Raval, Shah, \& Shah, 2016; Shakoor \& Nasar, 2017; Mashkoor \& Nasar, 2020b; Bulgariu et al., 2019; Kadhom, Albayati, Alalwan, \& Al-Furaiji, 2020), but there are other reports where it is mentioned that the best model are Langmuir and SIPS (Qian, Luo, Wang, Guo, \& Li, 2018; Mounia et al., 2018; He et al., 2019; Shakoor \& Nasar, 2016; Sun et al., 2019; Ma et al., 2018; Islam, Ahmed, Khanday, Asif, \& Hameed, 2017; Yang \& Guan, 2018; Lv et al., 2019; Marques-Fraga, Marques-Fraga, Da-Silva, Nascimento-Carvalho, \& DaMotta-Sobrinho, 2018a; Jaseela, Garvasis, \& Joseph, 2019; Pai, Srinivas, \& Selvaraj, 2019; Kadhom et al., 2020; Uddin \& Nasar, 2020; Mashkoor \& Nasar, 2020a; Marques-Fraga, Nascimento-Carvalho, Marques-Fraga, Da-Silva, Ferreira, \& Da-Motta-Sobrinho, 2018b; Mashkoor \& Nasar, 2020a; Nogueira-De-Paiva, Marques, Sales, Carvalho, \& Da-MottaSobrinho, 2018) and for the case of the use of hydroxyapatite as bioadsorbent for other dyes, the best models that adjust are Langmuir 
Tecnología y

Ciencias $₫$ Agua
2021, Instituto Mexicano de Tecnología del Agua

Open Access bajo la licencia CC BY-NC-SA 4.0

(https://creativecommons.org/licenses/by-nc-sa/4.0/)

and Freundlich, this was mentioned by Adeogun et al. (2018), Gross et al. (2017) and Pai et al. (2019).

Table 3. Equilibrium parameters for the $M B$ and $M O$ adsorption in nDCPD.

\begin{tabular}{|c|c|c|c|c|c|c|}
\hline \multirow{3}{*}{ Models } & \multicolumn{6}{|c|}{ Parameters } \\
\hline & \multicolumn{3}{|c|}{ MB } & \multicolumn{3}{|c|}{ MO } \\
\hline & $25^{\circ} \mathrm{C}$ & $35^{\circ} \mathrm{C}$ & $45^{\circ} \mathrm{C}$ & $25^{\circ} \mathrm{C}$ & $35^{\circ} \mathrm{C}$ & $45^{\circ} \mathrm{C}$ \\
\hline \multicolumn{7}{|l|}{ Langmuir } \\
\hline$K_{L}$ & 0.0953 & 0.1359 & 0.1902 & 0.0429 & 0.0221 & 0.0091 \\
\hline$q_{m}$ & 45.024 & 68.163 & 116.59 & 168.60 & 150.42 & 185.25 \\
\hline$R_{L}$ & $0.30-0.69$ & $0.17-0.60$ & $0.17-0.51$ & $0.32-0.70$ & $0.48-0.82$ & $0.69-0.92$ \\
\hline$R^{2}$ & 0.8205 & 0.7110 & 0.4348 & 0.7897 & 0.9962 & 0.6306 \\
\hline$\Delta q, \%$ & 0.6124 & 2.3250 & 15.729 & 0.8088 & 5.5108 & 35.2730 \\
\hline \multicolumn{7}{|l|}{ Freundlich } \\
\hline$K_{F}$ & 1.721 & 1.474 & 1.120 & 1.410 & 1.624 & 0.4396 \\
\hline$n$ & 0.9987 & 0.8253 & 0.6533 & 0.8216 & 0.8865 & 0.7158 \\
\hline$R^{2}$ & 0.9811 & 0.9866 & 0.9987 & 0.9976 & 0.9997 & 0.9964 \\
\hline$\Delta q, \%$ & 0.3867 & 0.5745 & 3.5920 & 0.2180 & 0.0157 & 0.1398 \\
\hline \multicolumn{7}{|l|}{ Temkin } \\
\hline$A$ & $5.1 * 10^{-19}$ & $6.3 * 10^{-18}$ & $5.6 * 10^{-18}$ & $1.4 * 10^{-16}$ & $1.2 * 10^{-16}$ & $3.2 * 10^{-17}$ \\
\hline B & 10.094 & 16.795 & 32.428 & 29.079 & 24.782 & 17.506 \\
\hline$R^{2}$ & 0.8065 & 0.7378 & 0.5137 & 0.6913 & 0.7196 & 0.6411 \\
\hline$\Delta q, \%$ & 12.011 & 10.9948 & 13.560 & 23.508 & 12.346 & 3.618 \\
\hline
\end{tabular}


Tecnología y

Ciencias $₫$ Agua
2021, Instituto Mexicano de Tecnología del Agua

Open Access bajo la licencia CC BY-NC-SA 4.0

(https://creativecommons.org/licenses/by-nc-sa/4.0/)

\begin{tabular}{|c|c|c|c|c|c|c|}
\hline \multicolumn{7}{|l|}{ SIPS } \\
\hline$K_{s}$ & 0.0823 & 0.0746 & 0.0797 & 0.0375 & 0.0403 & 0.0351 \\
\hline$q_{m}$ & 45.060 & 72.060 & 120.55 & 168.36 & 135.01 & 105.03 \\
\hline$\beta$ & 1.8553 & 3.2761 & 2.9857 & 2.677 & 2.767 & 2.858 \\
\hline$R^{2}$ & 0.8902 & 0.8984 & 0.7404 & 0.9508 & 0.9664 & 0.9380 \\
\hline$\Delta q, \%$ & 0.6487 & 0.09705 & 14.7444 & 0.7436 & 0.3615 & 0.6305 \\
\hline \multicolumn{7}{|l|}{$\mathbf{R P}$} \\
\hline$K_{R}$ & 10.005 & 29.441 & 0.1241 & 21.399 & 72.071 & 56.553 \\
\hline$a_{R}$ & 18.760 & 9.618 & 6.280 & 5.977 & 26.725 & 29.305 \\
\hline$n_{R P}$ & 0.014 & $5.1 * 10^{-17}$ & $2.6 * 10^{17}$ & $5.7 * 10^{-18}$ & $1.6 * 10^{-17}$ & $3.9 * 10^{-17}$ \\
\hline$R^{2}$ & 0.9611 & 0.9560 & 0.9100 & 0.9834 & 0.9974 & 0.9611 \\
\hline$\Delta q, \%$ & 207.0 & 413.08 & 43.95 & 244.22 & 1158.7 & 1176.3 \\
\hline \multicolumn{7}{|l|}{ DR } \\
\hline$q_{m}$ & 41.971 & 85.242 & 226.13 & 171.13 & 145.71 & 92.41 \\
\hline$k_{D R}$ & $1.7 * 10^{-5}$ & $2.6 * 10^{-5}$ & $4.1 * 10^{-5}$ & $8.2 * 10^{-5}$ & $7.5^{*} 10^{-5}$ & $6.5 * 10^{-5}$ \\
\hline$E^{a}$ & 169.74 & 139.93 & 111.80 & 78.326 & 81.675 & 87.666 \\
\hline$R^{2}$ & 0.8012 & 0.9406 & 0.9500 & 0.9188 & 0.9571 & 0.9061 \\
\hline$\Delta q, \%$ & 2.4618 & 8.2938 & 11.5204 & 1.4912 & 3.9385 & 4.8197 \\
\hline
\end{tabular}

In general, both models have been reported as the most suitable for adsorption of dyes and already depends on the criteria used to choose the best. The value of $\mathrm{n}<1$ for all temperatures implies that the adsorption on the surface of the bioadsorbent is a physical and favorable process, 


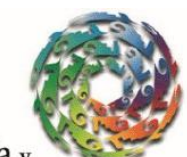

Ciencias $₫$ Agua
2021, Instituto Mexicano de Tecnología del Agua

Open Access bajo la licencia CC BY-NC-SA 4.0

(https://creativecommons.org/licenses/by-nc-sa/4.0/)

this was corroborated by Shakoor and Nasar (2017). The value of $R_{L}$ (Table 3) where at any temperature is less than 1 for $M O$ and MB (Hernández-Maldonado et al., 2017; Shakoor \& Nasar, 2017; Nogueira et al., 2018). The adsorption capacity obtained for MB were 44.42, 71.71 and $179.81 \mathrm{mg} / \mathrm{g}$ at 25,35 and $45^{\circ} \mathrm{C}$, respectively, where it can be noted that the higher temperature improves the adsorption of nDCPD, this coincides with the energy by absorbate molecular $(E)$ decreases with the temperature increase, which makes it easier to capture the dye and therefore a removal percentage of $97.1 \%$ at $45{ }^{\circ} \mathrm{C}$ was achieved.

Comparing to the results of the literature, the adsorption capacity of nDCPD of this dye is within the range between $1343-0.89 \mathrm{mg} / \mathrm{g}$, which gives us the guideline that it is a candidate for the removal of MB (Uyar et al., 2016; Li et al., 2016; Zong et al., 2018; Mudyawabikwa et al., 2017; Rahman, Kishimoto, Urabe, \& Ikeda, 2017; Islam et al., 2017; Yang \& Guan, 2018; Lv et al., 2019; Jaseela et al., 2019; Tara et al., 2020; Zhou et al., 2019). In the case of hydroxyapatite, it has an adsorption capacity between 417 to $34.1 \mathrm{mg} / \mathrm{g}$ between 25 and $40{ }^{\circ} \mathrm{C}$ (Pai et al., 2019), although it has a higher adsorption than nDCPD, it can be mentioned that the results obtained with nCDPD is within the values reported for hydroapatite, so we can mention that nDCPD is a candidate to remove MB from residues.

MO the adsorption capacity at 25,35 and $45^{\circ} \mathrm{C}$ obtained were $165.6,133.92$ and $62.44 \mathrm{mg} / \mathrm{g}$, respectively, where it can be inferred that the temperature has an adverse effect on the adsorption capacity of nDCPD, also, it is consistent with the result of the energy needed to remove an absorbent (Table 3) which increases with the increase in temperature and achieving a $99.4 \%$ removal capacity at $25{ }^{\circ} \mathrm{C}$. The 
values adsorption capacity that have been reported range from $392 \mathrm{mg} / \mathrm{g}$ to $46.08 \mathrm{mg} / \mathrm{g}$ (Raval et al., 2016; Sun et al., 2019; Ma et al., 2018; Rahman et al., 2017; Islam et al., 2017; Yang \& Guan, 2018; Zhou et al., 2019). A special case is the activated carbon obtained by calcination of grapefruit peel, it has an adsorption capacity of $680 \mathrm{mg} / \mathrm{g}$ (Kadhom et al., 2020). In the case of adsorption of dyes using Hydroxyapatite range from 135.1 to $21.1 \mathrm{mg} / \mathrm{g}$ (Pai et al., 2019). This shows that nDCPD can also be considered for the elimination of MO in the waters of industrial processes that use these dyes because it has a higher adsorption capacity than hydroxyapatite and compared to other adsorbents it has a very similar removal percentage (> 90) (Zhou et al., 2019; Kadhom et al., 2020).

\section{Thermodynamic study}

Thermodynamic analysis of the bioadsorption process is carried out from the obtaining of the adsorption isotherms (Table 4). For the case of MB there is a spontaneous process $(\Delta G<0)$ and endothermic process since the adsorption capacity increases directly with the increase in temperature, this was also obtained in several works using different bioadsorbents even with hydroxyapatite (Zhang et al., 2019; Adeogun et al., 2018; Shakoor \& Nasar, 2018; Mashkoor \& Nasar, 2020b; Shakoor \& Nasar, 2016; Raval et al., 2016; He et al., 2019). In addition, it has been 
mentioned that if the value of $\Delta H<40 \mathrm{~kJ} / \mathrm{mol}$ the adsorption is considered to be a physical process (Bulgariu et al., 2019).

Table 4. Thermodynamic parameters for $M B$ and $M O$ adsorption in nDCPD.

\begin{tabular}{|c|c|c|c|c|}
\hline \multicolumn{5}{|c|}{ MB } \\
\hline $\mathbf{T},{ }^{\circ} \mathrm{C}$ & $-\Delta G, \mathrm{~kJ} / \mathrm{mol}$ & $\Delta H, \mathrm{~kJ} / \mathrm{mol}$ & $\Delta S, \mathrm{~kJ} / \mathrm{mol} \mathrm{K}$ & $R^{2}$ \\
\hline 25 & 19.71 & \multirow{3}{*}{27.25} & \multirow{3}{*}{0.158} & \multirow{3}{*}{0.9989} \\
\hline 35 & 21.28 & & & \\
\hline 45 & 22.86 & & & \\
\hline \multicolumn{5}{|c|}{ MO } \\
\hline 25 & 17.89 & \multirow{3}{*}{-61.03} & \multirow{3}{*}{0.144} & \multirow{3}{*}{0.9896} \\
\hline 35 & 16.79 & & & \\
\hline 45 & 14.98 & & & \\
\hline
\end{tabular}

Although in some others it is mentioned that the process is exothermic (Guo et al., 2014; Cao et al., 2018), this could indicate that the nature of the process may depend on the surface where the removal of the dyes. In the case of MO the process is also spontaneous, however the process is exothermic $(\Delta H<0)$ implying that the adsorption capacity decreases with the increase in temperature, this was found in other studies (Uddin \& Baig, 2019; Raval et al., 2016; Qian et al., 2018; Bulgariu et al., 2019) that used activated carbon, furthermore the negative nature of the process allows forces with less intensity (compared to the latent heat of water vaporization) to be involved in the adsorption 
of dyes (Pessôa et al., 2019), although in some others the process that was found was endothermic (Islam et al., 2017; Yang \& Guan, 2018).

Considering this it can be said that the particle size can infer in the environment of the removal process. For both dyes, there is an irreversible process $(\Delta S>0)$, although it is worth mentioning that the value of this thermodynamic property is very small that it can be inferred that the dyes can have a desorption percentage, in addition to indicating that the affinity between MB, MO and nDCPD increases with the degree of freedom between the solid/liquid interface (Qian et al., 2018; Islam et al., 2017; Mashkoor \& Nasar, 2020a; Shakoor \& Nasar, 2018; Mashkoor \& Nasar, 2020b). Therefore, it confirms what was found in the study in balance, in addition to mentioning that the process is feasible.

\section{MB and MO bioadsorption kinetics}

Table 5 and Table 6 show the evolution of MB and MO adsorption in nDCPD concerning temperature along with the settings of the different kinetic models. It can be observed that PFO, PSO, and Elovich were the best models suit to the experimental data.

Table 5. Kinetic parameters of MB removal process in nDCPD.

\begin{tabular}{|c|c|c|c|c|c|}
\hline Model & $4 \mathrm{~g} / \mathrm{I}$ & $8 \mathrm{~g} / \mathrm{I}$ & $12 \mathrm{~g} / \mathrm{I}$ & $16 \mathrm{~g} / \mathrm{I}$ \\
\hline
\end{tabular}


Tecnología y

Ciencias $\stackrel{\Xi}{*}$ gua
2021, Instituto Mexicano de Tecnología del Agua

Open Access bajo la licencia CC BY-NC-SA 4.0

(https://creativecommons.org/licenses/by-nc-sa/4.0/)

\begin{tabular}{|c|c|c|c|c|c|c|c|c|c|c|c|c|c|c|c|}
\hline & $25^{\circ} \mathrm{C}$ & $35^{\circ} \mathrm{C}$ & $45^{\circ} \mathrm{C}$ & $25^{\circ} \mathrm{C}$ & $35^{\circ} \mathrm{C}$ & $45^{\circ} \mathrm{C}$ & $25^{\circ} \mathrm{C}$ & $35^{\circ} \mathrm{C}$ & $45^{\circ} \mathrm{C}$ & $25^{\circ} \mathrm{C}$ & $35^{\circ} \mathrm{C}$ & $45^{\circ} \mathrm{C}$ & $25^{\circ} \mathrm{C}$ & $35^{\circ} \mathrm{C}$ & $45^{\circ} \mathrm{C}$ \\
\hline \multicolumn{16}{|l|}{ PFO } \\
\hline$q_{\max }$ & 119.97 & 167.15 & 209.02 & 89.184 & 136.08 & 166.82 & 68.821 & 89.853 & 115.34 & 65.94 & 79.73 & 101.90 & 56.97 & 76.39 & 92.72 \\
\hline$k_{1}$ & 0.5578 & 0.4198 & 0.2858 & 0.7758 & 0.3558 & 0.3150 & 0.5907 & 0.4922 & 0.5015 & 0.4960 & 0.3569 & 0.5187 & 0.5971 & 0.5042 & 0.7916 \\
\hline$R^{2}$ & 0.9851 & 0.9642 & 0.9178 & 0.9669 & 0.9801 & 0.9404 & 0.9629 & 0.9045 & 0.9575 & 0.9843 & 0.9295 & 0.9586 & 0.9466 & 0.9632 & 0.9875 \\
\hline$\Delta q, \%$ & 1.7320 & 2.9393 & 3.3134 & 0.0362 & 1.8376 & 4.1870 & 4.4644 & 6.6468 & 4.2807 & 1.3204 & 3.3345 & 4.0245 & 4.6904 & 4.1959 & 5.6878 \\
\hline \multicolumn{16}{|l|}{ PSO } \\
\hline$q_{\max }$ & 124.36 & 185.02 & 198.44 & 89.31 & 145.27 & 150.70 & 77.758 & 103.35 & 130.83 & 67.71 & 89.90 & 115.29 & 64.20 & 86.74 & 103.95 \\
\hline$k_{2}$ & 0.0061 & 0.0034 & 0.0029 & 0.0130 & 0.0031 & 0.0022 & 0.0108 & 0.0063 & 0.0054 & 0.0092 & 0.0056 & 0.0064 & 0.0134 & 0.0081 & 0.0109 \\
\hline$R^{2}$ & 0.9863 & 0.9904 & 0.9626 & 0.9948 & 0.9938 & 0.9661 & 0.9914 & 0.9917 & 0.9993 & 0.9925 & 0.9820 & 0.9900 & 0.9935 & 0.9950 & 0.9957 \\
\hline$\Delta q, \%$ & 0.3015 & 1.1115 & 1.0784 & 0.0248 & 0.7945 & 0.1626 & 0.7567 & 0.9261 & 1.1490 & 0.1569 & 1.9442 & .3218 & 0.3912 & 1.2938 & 0.9593 \\
\hline \multicolumn{16}{|l|}{ Elovich } \\
\hline$a$ & 941.35 & 482.60 & 164.77 & 1908.4 & 245.71 & 186.99 & 510.98 & 326.79 & 520.44 & 277.10 & 175.68 & 523.76 & 462.73 & 341.80 & 1762.5 \\
\hline$\beta$ & 0.0531 & 0.0319 & 0.0187 & 0.0920 & 0.0360 & 0.0284 & 0.0899 & 0.0601 & 0.0496 & 0.0861 & 0.0649 & 0.0574 & 0.1103 & 0.0746 & 0.0763 \\
\hline$R^{2}$ & 0.9647 & 0.9902 & 0.8741 & 0.9910 & 0.9847 & 0.9037 & 0.9895 & 0.9622 & 0.9886 & 0.9519 & 0.9676 & 0.9812 & 0.9833 & 0.9924 & 0.9476 \\
\hline$\Delta q, \%$ & 3.2913 & 7.9766 & 6.2775 & 5.1335 & 8.0788 & 7.6590 & 6.7025 & 7.9793 & 7.6964 & 4.5013 & 9.6970 & 7.3993 & 6.5364 & 7.6801 & 5.2249 \\
\hline \multicolumn{16}{|l|}{ DI } \\
\hline$k_{i d}$ & 36.397 & 48.752 & 54.373 & 25.544 & 38.186 & 42.213 & 21.277 & 27.349 & 34.823 & 19.61 & 25.53 & 30.91 & 17.68 & 23.07 & 29.73 \\
\hline$R^{2}$ & 0.4213 & 0.6176 & 0.6457 & 0.3753 & 0.6750 & 0.6314 & 0.4907 & 0.6461 & 0.5622 & 0.4753 & 0.6841 & 0.5411 & 0.4954 & 0.5604 & 0.4156 \\
\hline$\Delta q, \%$ & 7.3114 & 11.366 & 10.192 & 8.8524 & 11.436 & 11.274 & 10.239 & 11.220 & 11.066 & 8.4446 & 9.0747 & 10.850 & 10.035 & 11.088 & 8.8487 \\
\hline \multicolumn{16}{|l|}{$\overline{D E}$} \\
\hline$k_{\text {ext }}$ & 22.16 & 26.57 & 20.01 & 37.39 & 31.4015 & 20.10 & 40.52 & 48.88 & 63.026 & 38.92 & 49.39 & 76.09 & 60.07 & 68.53 & 108.01 \\
\hline$R^{2}$ & 0.0 & 0.0 & 0.0 & 0.0 & 0.0 & 0.0 & 0.0 & 0.0 & 1 & 0.0 & 0.0 & 0.0 & 0.0 & 0.0 & 0.0006 \\
\hline$\Delta q, \%$ & 66.181 & 122.23 & 134.05 & 116.59 & 215.22 & 240.65 & 164.73 & 232.15 & 0.0 & 197.86 & 278.08 & 365.58 & 242.06 & 341.38 & 417.21 \\
\hline & & & & & & & & & 305.06 & & & & 3 & & \\
\hline
\end{tabular}

Table 6. Kinetic parameters of MO adsorption in nDCPD.

\begin{tabular}{|c|c|c|c|c|c|c|c|c|c|c|c|c|c|c|c|}
\hline \multirow[t]{2}{*}{ Model } & \multicolumn{3}{|c|}{$4 \mathrm{~g} / 1$} & \multicolumn{3}{|c|}{$8 \mathrm{~g} / 1$} & \multicolumn{3}{|c|}{$12 \mathrm{~g} / 1$} & \multicolumn{3}{|c|}{$16 \mathrm{~g} / 1$} & \multicolumn{3}{|c|}{$20 \mathrm{~g} / 1$} \\
\hline & $25^{\circ} \mathrm{C}$ & $35^{\circ} \mathrm{C}$ & $45^{\circ} \mathrm{C}$ & $25^{\circ} \mathrm{C}$ & $35^{\circ} \mathrm{C}$ & $45^{\circ} \mathrm{C}$ & $25^{\circ} \mathrm{C}$ & $35^{\circ} \mathrm{C}$ & $45^{\circ} \mathrm{C}$ & $25^{\circ} \mathrm{C}$ & $35^{\circ} \mathrm{C}$ & $45^{\circ} \mathrm{C}$ & $25^{\circ} \mathrm{C}$ & $35^{\circ} \mathrm{C}$ & $45^{\circ} \mathrm{C}$ \\
\hline PFO & & & & & & & & & & & & & & & \\
\hline$q_{\max }$ & 148.02 & 106.11 & 49.125 & 66.014 & 95.663 & 26.633 & 39.437 & 65.021 & 32.189 & 34.057 & 68.224 & 26.526 & 60.125 & 56.192 & 33.281 \\
\hline$k_{1}$ & 0.0782 & 1.2719 & 0.4265 & 0.2493 & 0.4534 & 0.48687 & 0.2498 & 1.0822 & 2.4494 & 0.6131 & 0.7408 & 0.6650 & 0.1460 & 0.7956 & 0.9706 \\
\hline$R^{2}$ & 0.9861 & 0.9947 & 0.8551 & 0.9614 & 0.9755 & 0.7837 & 0.9825 & 0.9930 & 0.9511 & 0.9535 & 0.9347 & 0.8611 & 0.9442 & 0.9595 & 0.9485 \\
\hline$\Delta q, \%$ & 6.0967 & 0.3290 & 2.3190 & 1.4656 & 0.1789 & 2.7065 & 1.8206 & 1.0943 & 2.3451 & 0.2208 & 2.1354 & 0.7116 & 0.2680 & 1.5822 & 5.4550 \\
\hline PSO & & & & & & & & & & & & & & & \\
\hline
\end{tabular}


Tecnología y

Ciencias $\stackrel{\Xi}{\approx}$ Aua
2021, Instituto Mexicano de Tecnología del Agua

Open Access bajo la licencia CC BY-NC-SA 4.0

(https://creativecommons.org/licenses/by-nc-sa/4.0/)

\begin{tabular}{|c|c|c|c|c|c|c|c|c|c|c|c|c|c|c|c|}
\hline$q_{\max }$ & 219.63 & 102.47 & 55.497 & 79.391 & 86.046 & 29.717 & 44.401 & 61.502 & 31.014 & 34.935 & 66.506 & 24.834 & 76.247 & 50.385 & 30.782 \\
\hline$k_{2}$ & 0.0003 & 0.0279 & 0.0101 & 0.0034 & 0.0068 & 0.0225 & 0.0074 & 0.0269 & 0.2029 & 0.0292 & 0.0123 & 0.0375 & 0.0019 & 0.0202 & 0.0337 \\
\hline$R^{2}$ & 0.9856 & 0.9825 & 0.7928 & 0.9292 & 0.9489 & 0.7180 & 0.9601 & 0.9430 & 0.9457 & 0.9309 & 0.7998 & 0.8364 & 0.9328 & 0.9327 & 0.8374 \\
\hline$\Delta q, \%$ & 25.172 & 1.4607 & 6.9427 & 8.5155 & 3.5152 & 6.8754 & 2.1513 & 2.8416 & 3.4702 & 0.2680 & 1.5822 & 1.4478 & 9.2789 & 2.0289 & 2.2360 \\
\hline \multicolumn{16}{|l|}{ Elovich } \\
\hline$a$ & 0.025 & 0.0459 & 0.1014 & 0.0556 & 0.0665 & 0.2118 & 0.1183 & 0.0777 & 0.1849 & 0.2273 & 0.1006 & 0.311 & 0.0650 & 0.1481 & 0.2282 \\
\hline$\beta$ & 32.735 & 250.67 & 100.19 & 41.377 & 335.66 & 94.483 & 42.161 & 158.02 & 205.60 & 530.69 & 347.69 & 434.94 & 27.86 & 622.65 & 475.18 \\
\hline$R^{2}$ & 0.9453 & 0.8189 & 0.7203 & 0.9013 & 0.9369 & 0.6430 & 0.9125 & 0.9055 & 0.8579 & 0.9298 & 0.8776 & 0.8046 & 0.9347 & 0.9134 & 0.9008 \\
\hline$\Delta q, \%$ & 40.806 & 40.821 & 40.816 & 40.793 & 40.811 & 40.798 & 40.813 & 40.816 & 40.817 & 40.345 & 40.573 & 43.097 & 49.052 & 55.123 & 49.901 \\
\hline \multicolumn{16}{|l|}{ ID } \\
\hline$k_{i d}$ & 24.84 & 29.81 & 13.18 & 16.46 & 23.93 & 7.23 & 9.73 & 17.95 & 9.26 & 9.145 & 17.173 & 6.945 & 13.191 & 13.541 & 9.015 \\
\hline$R^{2}$ & 0.9624 & 0.0073 & 0.3770 & 0.7538 & 0.6631 & 0.2634 & 0.8592 & 0.2638 & 0.0121 & 0.4315 & 0.6285 & 0.2826 & 0.9329 & 0.5016 & 0.5034 \\
\hline$\Delta q, \%$ & 17.948 & 22.811 & 33.399 & 20.219 & 22.408 & 35.763 & 21.388 & 32.912 & 25.724 & 25.724 & 19.474 & 34.090 & 17.856 & 23.372 & 31.134 \\
\hline \multicolumn{16}{|l|}{ ED } \\
\hline$k_{\text {ext }}$ & 111.77 & 30.117 & 3.86 & 205.58 & 30.863 & 3.182 & 251.37 & 48.944 & 31.249 & 29.766 & 46.958 & 107.26 & 197.38 & 51.259 & 36.386 \\
\hline$R^{2}$ & 0.0 & 0.0 & 0.0 & 0.0 & 0.0 & 0.0 & 5 & 0.0 & 0.0 & 0.0 & 0.0 & 0.0 & 0.0 & 0.0 & 0.0 \\
\hline$\Delta q, \%$ & 66.161 & 142.28 & 134.03 & 116.59 & 116.59 & 215.22 & 0.0443 & 164.73 & 232.15 & 191.85 & 276.08 & 365.58 & 242.06 & 341.38 & 417.22 \\
\hline & & & & & & & 240.65 & & & & & & 3 & & \\
\hline
\end{tabular}

To choose the best fit, the $R^{2}$ and $\Delta q$ criteria (Table 5) were used, obtaining for the MB case the best model that fits is PSO, indicating that the adsorption of the dye on the surface of nDCPD needs two active sites, according to the published in various jobs this is the best model for the adsorption of MB with different adsorbents (Kwak et al., 2018; Zhang et al., 2019; Uddin \& Baig, 2019; Varaprasad et al., 2018; Liu et al., 2019; Zong et al., 2018; Mudyawabikwa et al., 2017; Jaseela et al., 2019; Uddin \& Nasar, 2020; Mashkoor \& Nasar, 2020a; Pessôa et al., 2019; Bulgariu et al., 2019), while for MO (Table 6) the most appropriate fit is the PFO model involves that only need an one active site to capture the dye, in this case, has been mentioned that the best model for this dye is PFO model (Mounia et al., 2018; Yang \& Guan, 2018; Lima et al., 2015), it 


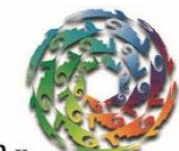

Ciencias $₫$ Agua
2021, Instituto Mexicano de Tecnología del Agua

Open Access bajo la licencia CC BY-NC-SA 4.0

(https://creativecommons.org/licenses/by-nc-sa/4.0/)

means that the structure of the material which contains a $\mathrm{Ca} / \mathrm{P}$ ratio greater than 1 significantly influences the adsorption.

Although there are investigations where mention that the adsorption kinetics of MO is PSO is equal as MB (Mashkoor \& Nasar, 2020b; Bulgariu et al., 2019; Kadhom et al., 2020), which indicates that nCDPD only needs one site to carry out the adsorption of the dye compared to other adsorbents that need two sites to carry out this process. It can also be mentioned that adsorption has no limitations by mass transfer since both intraparticle and external diffusion models are the least suitable for simulating experimental data. In the case of $M B$, it has an adsorption capacity of $193.33 \mathrm{mg} / \mathrm{g}$ to $45^{\circ} \mathrm{C}$, with this value can be inferred that nDCPD has a suitable adsorption capacity, since the reported values are between 434.7 to $23.3 \mathrm{mg} / \mathrm{g}$ (Guo et al., 2014; DoNascimiento et al., 2014; Tabrizi \& Yavari, 2015; Uyar et al., 2016; Li et al., 2016; Zong et al., 2018; Mudyawabikwa et al., 2017; Mounia et al., 2018; He et al., 2019; Shakoor \& Nasar, 2016; Sun et al., 2019; Jaseela et al., 2019) while for MO have $125.14 \mathrm{mg} / \mathrm{g}$ of adsorption capacity at 25 ${ }^{\circ} \mathrm{C}$, which also means that can be an appropriate candidate to remove this dye because in the literature the values mentioned are $321-8.474 \mathrm{mg} / \mathrm{g}$ (Uddin \& Baig, 2019; Mounia et al., 2018; Ma et al., 2018; Islam et al., 2017; Shakoor \& Nasar, 2018; Mashkoor \& Nasar, 2020b; Kadhom et al., 2020).

In the case of the use of Hydroxyapatite have been reported to remove other dyes showing an adsorption capacity from 362.3 to 11.88 $\mathrm{mg} / \mathrm{g}$ being that $\mathrm{nDCPD}$ is within this range, it has been thought to continue studying its capabilities to remove other dyes in addition to MO and MB (Panneerselvam et al., 2019; Cao et al., 2018; Guan, Cao, Wang, 
Marchetti, \& Tu, 2018; Lemlikchi et al., 2015; Pai et al., 2019). Figure 4 shows the effect on adsorption capacity for both dyes, being that by increasing the concentration of the bioadsorbent increases the removal percentage this might be because there are more active sites which can capture more molecules of the dyes on the surface, this is consistent with what was reported in the literature for certain intervals of $\mathrm{C}_{\text {ads }}$ (Pargoletti et al., 2019; Zhang et al., 2019; Liu et al., 2019; Tabrizi \& Yavari, 2015; Uyar et al., 2016; Lv et al., 2019).
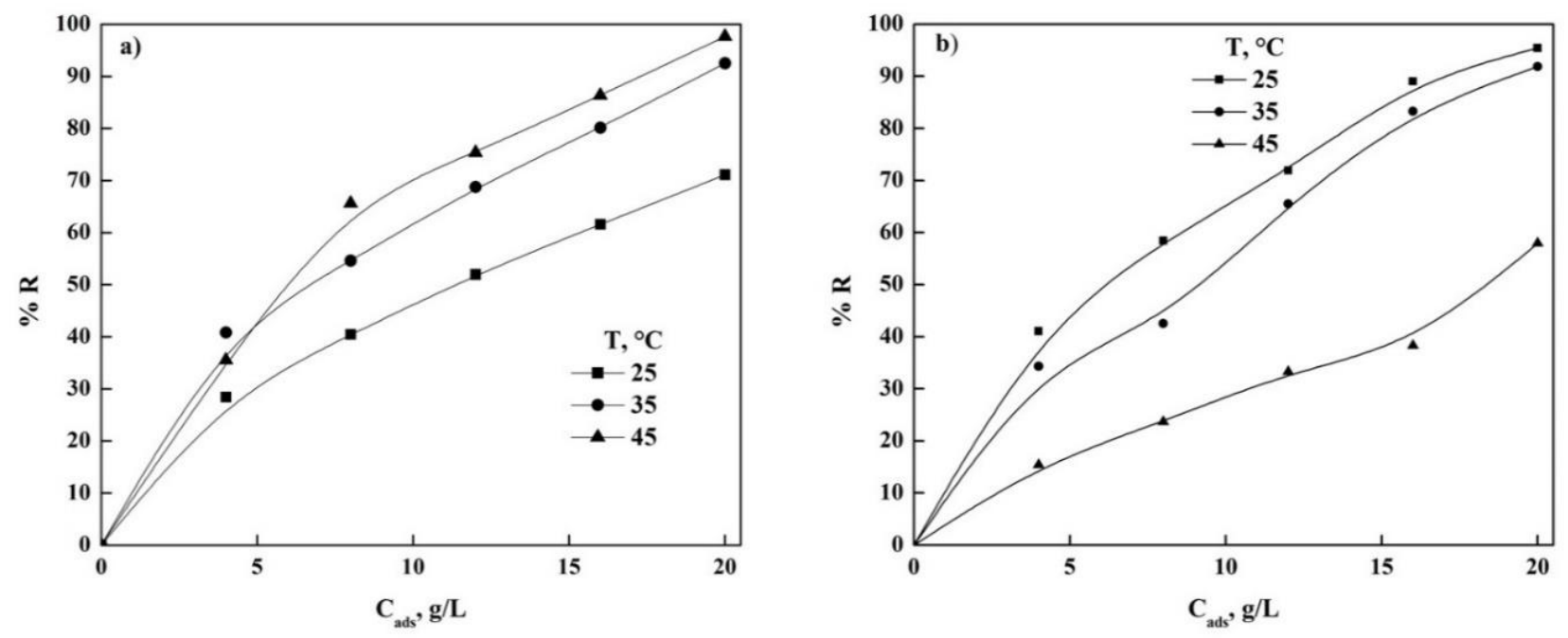

Figure 4. Removal percentage at different temperatures: a) MB and b) MO.

$M B$ and $M O$ are cationic and anionic dyes, respectively, it has been reported that the zero load potential (PZC) of nDCPD is 6.3 (HernándezMaldonado et al., 2017), implying that at $\mathrm{pH}$ less than this value, the surface is positively charged, which makes $\mathrm{MO}$ adsorption $(\mathrm{pH}$ of 5.91) 
easier at lower temperature and for $\mathrm{MB}$ ( $\mathrm{pH}$ of 4.52 ) energy has to be added for the adsorption to be carried out given its nature in solution and also as indicated by other authors (Srilakshmi \& Saraf, 2016; HernándezMaldonado et al., 2017) instead of using electrostatic attraction in surface and dye is done by an ion exchange. Based on these results nDCPD extracted from bovine bone represents an option to assist industries and the environment in water care used in the manufacturing processes of various products.

\section{Characterization of nDCPD}

Figure 5 shows the nDCPD FTIR spectra and the samples used to adsorb $\mathrm{Mb}$ and MO. In the samples there is the band at $3292 \mathrm{~cm}^{-1}$ that can be assigned to the $\mathrm{O}-\mathrm{H}$ stretch of the water molecule found in the nDCPD structure (Cao et al., 2018; Hernández-Soto et al., 2019). The peaks at 2923 and $1210 \mathrm{~cm}^{-1}$ represent the $\mathrm{PO}-\mathrm{H}$ stretch of the $\mathrm{HPO}_{4}{ }^{2-}$ group and the bending in the $\mathrm{O}-\mathrm{H}$ plane (Hernández-Maldonado et al., 2017; Pakshiranja et al., 2013; Arifuzzaman \& Rohani, 2004; Sopcak et al., 2016). The peaks at 1 100, 1078 (shoulder), 960 (shoulder) and $871 \mathrm{~cm}^{-}$ 1 are assigned to the presence of the $\mathrm{P}-\mathrm{O}$ and $\mathrm{P}-\mathrm{O}(\mathrm{H})$ stretch present in the $\mathrm{HPO}_{4}{ }^{2-}$ group together with double to 575 and $530 \mathrm{~cm}^{-1}$ which can be assigned to the bending vibrations of O-P-O of the nDCPD phosphate group (Hernández-Soto et al., 2019; Sopcak et al., 2016). The vibrations 


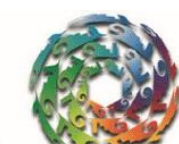

Ciencias $₫$ Agua
2021, Instituto Mexicano de Tecnología del Agua

Open Access bajo la licencia CC BY-NC-SA 4.0

(https://creativecommons.org/licenses/by-nc-sa/4.0/)

of the physically linked water were found at 1647 and $668 \mathrm{~cm}^{-1}$, in addition to finding at 1418 and $880 \mathrm{~cm}^{-1}$ bands related to the carbonate groups of the apatite present in the sample. The vibrational stretch of the $\mathrm{PO}_{4}{ }^{3-}$ group was observed at $598 \mathrm{~cm}^{-1}$ (Hernández-Soto et al., 2019; Islam et al., 2017; Sopcak et al., 2016). All groups participate in the adsorption of dyes on the surface because their intensities are significantly affected by the presence of MB and MO. It should be noted that the intensity of the nDCPD MO spectrum decreases compared to the nDCPD spectrum, which may indicate that there is greater participation of each of the groups in catching MO on its surface which confirms that there is a greater affinity for adsorbing the anionic dye on the cationic.

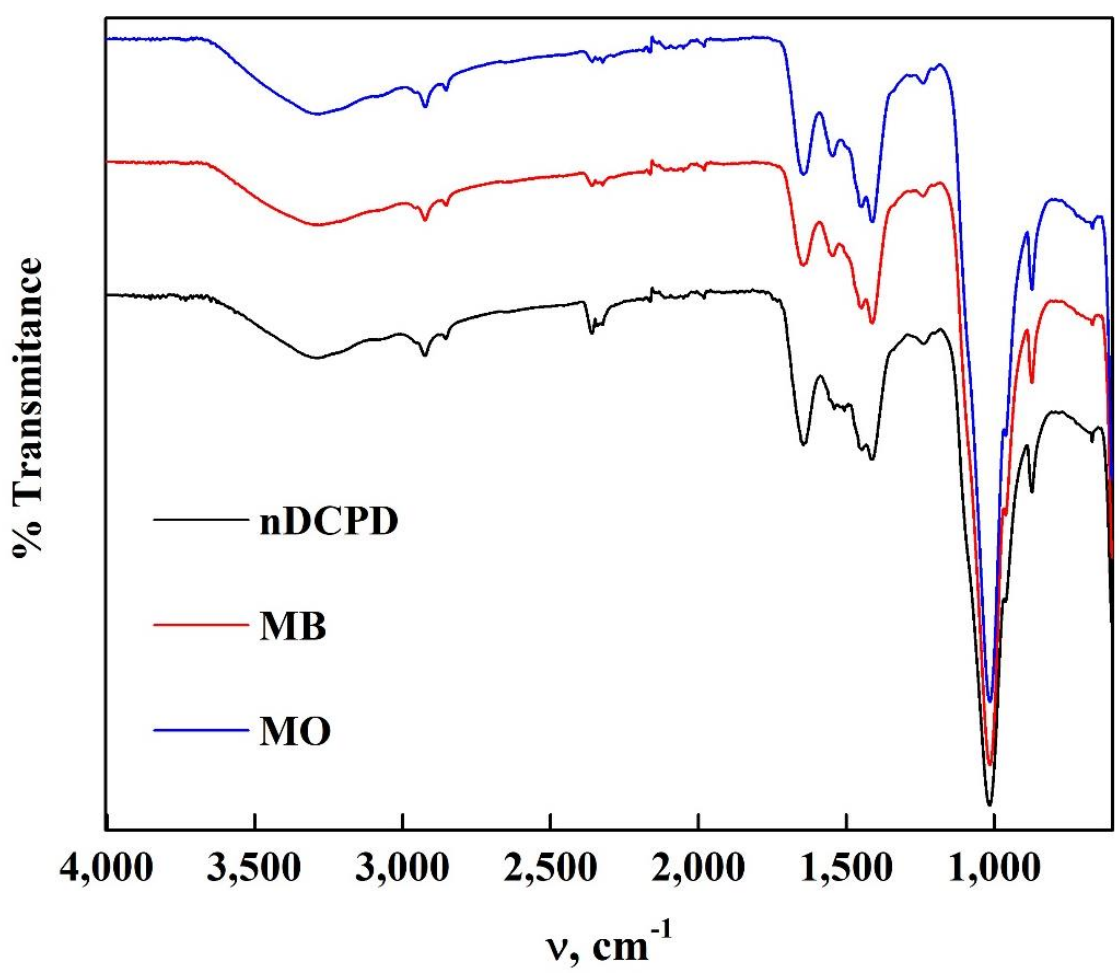

Figure 5. FIIR spectrum for $\mathrm{nCDPD}$ used for adsorption of $M O$ and MB. 


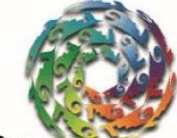

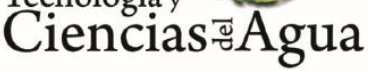

2021, Instituto Mexicano de Tecnología del Agua

Open Access bajo la licencia CC BY-NC-SA 4.0

(https://creativecommons.org/licenses/by-nc-sa/4.0/)

SEM micrographs of nDCPD are seen in Figure 6a, well-defined monoclinic plate morphology, characteristic of Brushite (Yang et al., 2019). Figure $6 \mathrm{~b}$ reveals small weights of this apatite, possibly due to the fact that the small grains that form around the nDCPD plate have broken due to the adsorption of the dyes (Mirković et al., 2016).

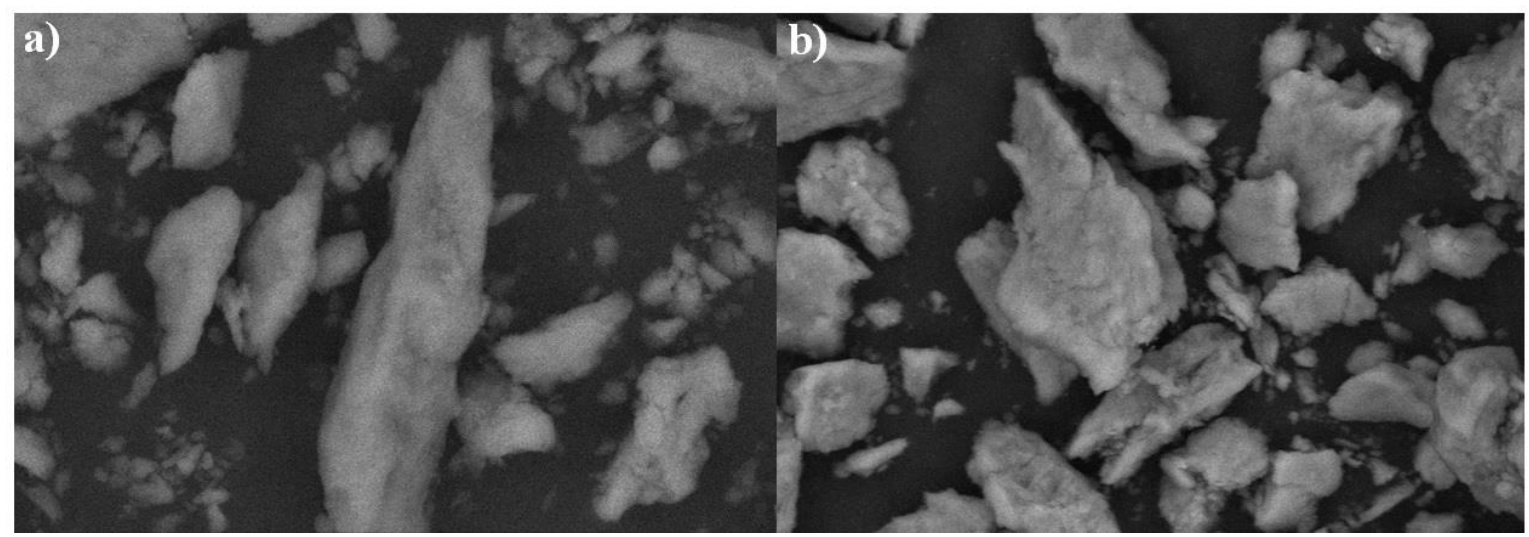

Figure 6. SEM micrograph of Ncdpd: a) $5 \mu \mathrm{m}$ y b) $10 \mu \mathrm{m}$.

The nDCPD adsorption-desorption isotherm shown in Figure 7 evidences that the sample has a type IV isotherm, which is related to a structured porous structure (Mashkoor \& Nasar, 2020a; Sing, 1985; Zhou et al., 2014; Türk et al., 2018), with a surface area of $1.16 \mathrm{~m}^{2} / \mathrm{g}$. In the box in Figure 7, look at the pore size distribution ranging from 2 to $16 \mathrm{~nm}$ (average diameter equal to $6.05 \mathrm{~nm}$ ) allowing it to be a mesoporous structure (pore size 2-50 nm). In the works reported by Pessôa et al. (2019), and Mashkoor and Nasar (2020a), where also adsorb dyes, the materials used has pore diameter between 1.98 to $2.6 \mathrm{~nm}$ and have low 
areas compared to other adsorbents such as activated carbon among others (Marques-Fraga et al., 2018b) in such a way that these characteristics are similar to those obtained in our material, we can infer that not only the dyes are adsorbed on the surface of the material, it can also enter the nCDPD pore so that they are adsorbed inside.

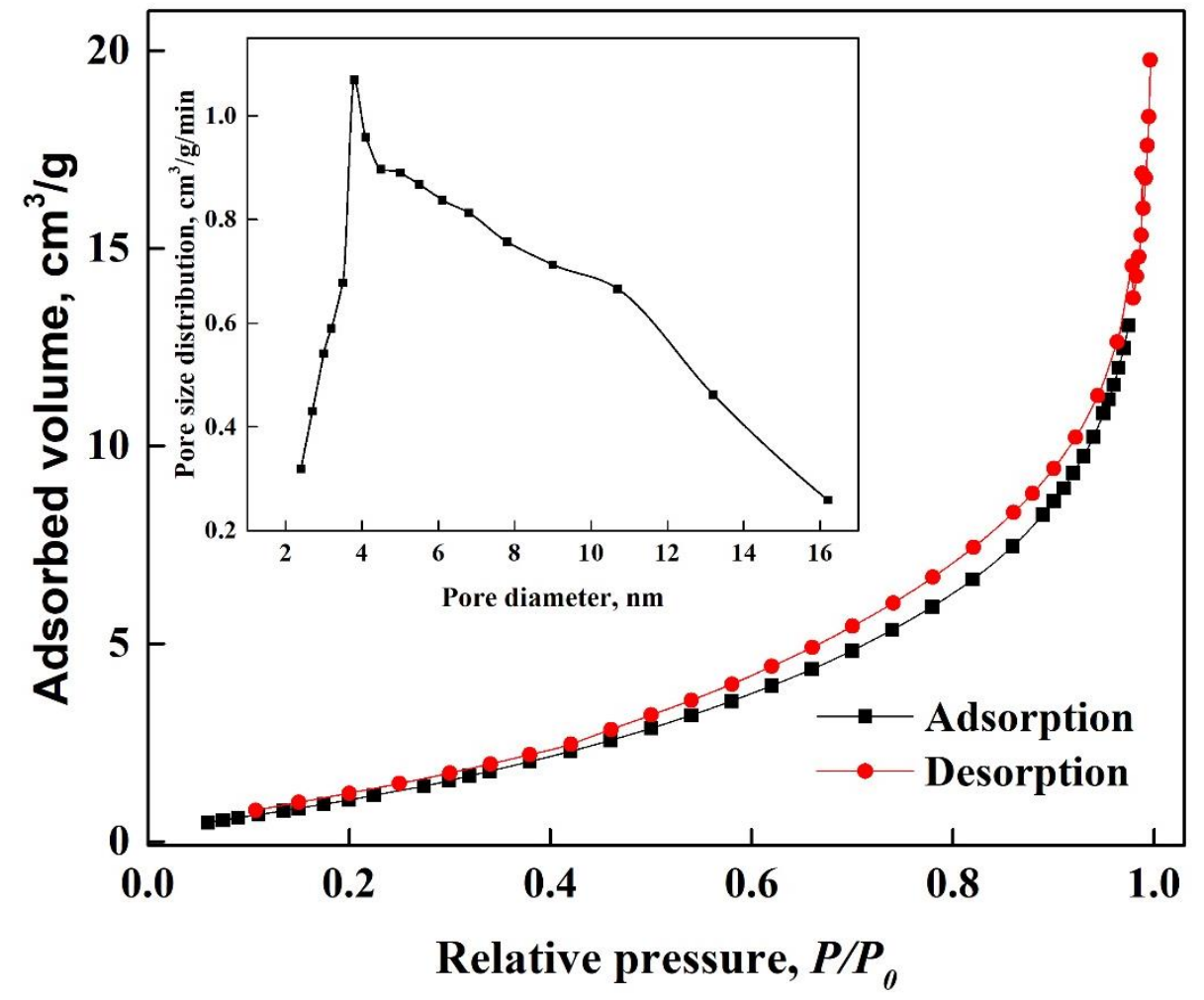

Figure 7. Adsorption-desorption isotherm (pore size distribution).

\section{Conclusions}




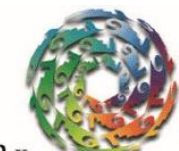

Ciencias: ฐึgua
2021, Instituto Mexicano de Tecnología del Agua

Open Access bajo la licencia CC BY-NC-SA 4.0

(https://creativecommons.org/licenses/by-nc-sa/4.0/)

The results obtained in this work show that nDCPD from the bovine bone has a great capacity to absorb MB and MO dyes, since a removal percentage of 97.1 and $99.4 \%$ was obtained, respectively. Adsorption kinetics revealed that external and intraparticle mass transfer does not limit the adsorption phenomenon and that depending on the dye one or two active sites must be used to carry out this process. It was also found that the process is spontaneous, irreversible, but for MB it is endothermic and for $\mathrm{MO}$ is exothermic, indicating that the adsorption process depends heavily on temperature and this causes the energy needed to remove the dye to increase or decrease depending on the nature of the dye. In this case, nDCPD absorbs more quantity and more easily (less energy) to anionic dyes, since at room temperature the maximum adsorption capacity of MO is obtained, otherwise for MB that is a cationic dye more energy is needed to remove it from the solution, in addition to considering the nature of the surface of the bioadsorbent that uses electrostatic interaction to eliminate $\mathrm{MO}$, while for $\mathrm{MB}$ the ion exchange is used preferably to remove it from the medium.

The model that best suits the data obtained regardless of the dye in the balance was Freundlich's, allowing to mention the bioadsorption is carried out on a heterogeneous surface allowing each site to have its adsorption energy. The textural properties of nDCPD indicate that they are suitable for the adsorption of both dyes to be carried out, since they can detect this process on the surface and inside the adsorbent. In nDCPD micrographs was observed the classical monoclinic plaque structure in the 
material. FIIR results allow us to determine that several groups are involved in the removal of dyes. Based on these results we can say that nDCPD is a good candidate to clean process waters from industries that use dyes because their costs are very accessible, easy to obtain and that they have a high efficiency where have to take the significant effects of temperature and concentration of bioadsorbent.

\section{Acknowledgment}

The authors would like to thank the Mining, Metallurgy and Geology Engineering Department of Guanajuato University and UPIIG-IPN for the infrastructure provided to carry out this project. The authors also want to thank the Research and Postgraduate Secretariat for the financial support for this work (SIP: 20190038).

\section{References}

Abdullah, N. H., Abdul-Ghani, N. A., Razab, M. K. A. A., Noor, A. M., Halim, A. Z. A., Rasat, M. S. M., Wong, K. N. S. W. S., \& Amin, M. F. M. (Febrruary 2019). Methyl orange adsorption from aqueous solution by corn cob based activated carbon. AIP Conference Proceeding, 2068, 020036, Klantan, Malaysia

Adeogun, A. I., Ofudje, E. A., Idowu, M. A., Kareem, S. O., Vahidhabanu, S., \& Babu, S. R. (2018). Biowaste-derived hydroxyapatite for effective removal of reactive yellow 4 dye: Equilibrium, kinetic, and thermodynamic studies. ACS Omega, 3(2), 1991-2000. 
Altintig, E., Altundag, H., Tuzen, M. B. I., \& Sarl, A. (2017). Effective removal of methylene blue from aqueous solutions using magnetic loaded activated carbon as novel adsorbent. Chemical Engineering Research and Design, 122, 151-163.

Arifuzzaman, S. M., \& Rohani, S. (2004). Experimental study of brushite precipitatioN. Journal of Crystal Growth, 267 (3-4), 624-634.

Bhatia, D., Sharma, N. R., Singh, J., \& Kanwar, R. S. (2017). Biological methods for textile dye removal from wastewater: A review. Critical Reviews Environmental Science Technology, 47(19), 1836-1876.

Bulgariu, L., Escudero, L. B., Bello, O. S., Iqbal, M., Nisar, J., Adegoke, K. A., Alakhras, F., Kornaros, M., \& Anastopoulos, I. (2019). The utilization of leaf-based adsorbents for dyes removal: A review. Journal of Molecular Liquids, 276, 728-747.

Cai, Z., Sun, Y., Liu, W., Pan, F., Sun, P., \& Fu J. (2017). An overview of nanomaterials applied for removing dyes from wastewater. Environmental Science and Pollution Research, 24(19), 1588215904.

Cao, Y.-L., Pan, Z.-H., Shi, Q.-X., \& Yu, J.-Y. (2018). Modification of chitin with high adsorption capacity for methylene blue removal. International Journal Biological Macromolecules, 114, 392-399.

Cheng, Z., Liao, J., He, B., Zhang, F., Zhang, F., Huang, X., \& Zhou, L. (2015). One-step fabrication of graphene oxide enhanced magnetic composite gel for highly efficient dye adsorption and catalysis. ACS Sustainable Chemical and Engineering, 3(7), 1677-1685. 


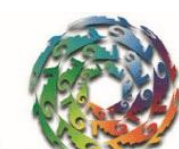

Tienologigy

Do-Nascimiento, G. E., Menezes, B. D. M. M., Ferreira, C. N., Sá-daRocha, O. R., \& Da-Silva, B. L. (2014). Adsorption of azo dyes using peanut hull and orange peel: a comparative study. Environmental Technology, 35(11), 1436-1453.

Doan, P. M., Dung-Tran, N., Nzihou, A., \& Sharrock, P. (2014). Calcium phosphate based materials starting from calcium carbonate and orthophosphoric acid for the removal of lead(II) from an aqueous solution. Chemical Engineering Journal, 243, 280-288.

El-Hamidi, A., Mulongo-Masamba, R., Khachani, M., Halim, M., \& Arsalane, S. (2015). Kinetics modeling in liquid phase sorption of copper ions on brushite di-calcium phosphate di-hydrate CaHPO4.2H2O (DCPD). Desalination and Water Treatment, 56(3), 779-791.

Farroq, U., Kozinski, J. A., Khan, M. A., \& Athar, M. (2010). Biosorption of heavy metal ions using wheat based biosorbents-A review of the recent literature. Bioresource Technology, 101(14), 5043-5053.

Gross, M., Lima, M. T., Uhlig, M., Ebraheme, A., Roeber, O., Olschewski, B., von Klitzing, R., Schomäcker, R., \& Schwarze, M. (2017). Biopolymers for dye removal via foam separation. Separation and Purification Technology, 188, 451-457.

Guan, Y., Cao, W., Wang, X., Marchetti, A., \& Tu, Y. (2018). Hydroxyapatite nano-rods for the fast removal of congo red dye from aqueous solution. Materials Research Express, 5(6), 065053.

Guo, J. Z., Li, B., Liu, L., \& Lv, K. (2014). Removal of methylene blue from aqueous solutions by chemically modified bamboo. Chemosphere, 111, 225-231. 
He, K., Zeng, G., Chen, A., Huang, Z., Peng, M., Huang, T., \& Chen, G. (2019). Graphene hybridized polydopamine-kaolin composite as effective adsorbent for methylene blue removal. Composites Part $B$, $161,141-149$.

Hernández-Maldonado, J. A., Torres-García, F. A., Salazar-Hernández, M. M., \& Hernández-Soto, R. (2017). Removal of chromium from contaminated liquid effluents using natural brushite obtained from bovine bon. Desalination and Water Treatment, 95, 262-273.

Hernández-Soto, R., Hernández, J. A., Ardila-Arias, A. N., SalazarHernández, M. M., \& Salazar-Hernandez, M. C. (2019). The use of industrial waste for the bioremediation of water used in industrial processes. Water Chemistry, 1, Chapter 1, 1-19.

Holkar, C. R., Jadhav, A. J., Pinjari, D. V., Mahamuni, N. M., \& Pandit, A. B. (2019). A critical review on textile wastewater treatments: Possible approaches. Journal of Environmental Management, 182, 351-366.

Islam, M. A., Ahmed, M. J., Khanday, W. A., Asif, M., \& Hameed, B. H. (2017). Mesoporous activated carbon prepared from $\mathrm{NaOH}$ activation of rattan (Lacosperma secundiflorum) hydrochar for methylene blue removal. Ecotoxicology Environmental Safety, 138, 279-285.

Jaseela, P. K., Garvasis, J., \& Joseph, A. (2019). Selective adsorption of methylene blue (MB) dye from aqueous mixture of $M B$ and methyl orange (MO) using mesoporous titania (TiO2) - poly vinyl alcohol (PVA) nanocomposite. Journal of Molecular Liquids, 286, 110908-1. 


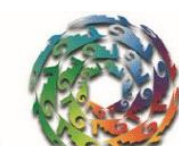

Tienologigy

Kadhom, M., Albayati, N., Alalwan, H., \& Al-Furaiji, M., D. (2020). Removal of dyes by agricultural waste. Sustainable Chemistry and Pharmacy, 16, 100259.

Kwak, H. W., Hong, Y., Lee, M. E., \& Jin, H.-J. (2018). Sericin-derived activated carbon-loaded alginate bead: An effective and recyclable natural polymer-based adsorbent for methylene blue removal. International Journal of Biological Macromolecules, 120, 906-914.

Kyzas, G. Z., Bikiaris, D. N., \& Mitropoulos, A. C. (2017). Chitosan adsorbents for dye removal: A review. Polymer International, 66(12), 1800-1811.

Lemlikchi, W., Drouiche, N., Belaicha, N., Oubagha, N., Baaziz, S., \& Mecherri, M. O. (2015). Kinetic study of the adsorption of textile dyes on synthetic hydroxyapatite in aqueous solution. Journal of Industrial and Engineering Chemistry, 32, 233-237.

Li, D-Q., Wang, J., Guo, Z. G., Li, J., \& Shuai, J. (2017). Pectin gels cross linked by $\mathrm{Ca}^{2+}$ : An efficient material for methylene blue removal. Journal of Molecular Liquids, 238, 36-42.

Li, G., Zhu, W., Zhang, C., Zhang, S., Liu, L., Zhu, L., \& Zhao, W.-G. (2016). Effect of a magnetic field on the adsorptive removal of methylene blue onto wheat straw biochar. Bioresource Technology, 206, 16-22.

Lima, T. A. R. M., Brito, N. S., Peixoto, J. A., \& Valerio, M. E. G. (2015). The incorporation of chromium (III) into hydroxyapatite crystals. Materials Letters, 140, 187-191. 
Liu, Q., Li, Y., Chen, H., Lu, J., Yu, G., Möslang, M., \& Zhou, Y. (2019). Superior adsorption capacity of funcionalised straw adsorbent for dyes and heavy-metal ions. Journal of Hazardous Materials, 383, 113.

Lv, S.-W., Liu, J.-M., Ma, H., Wang, Z.-H., Li, C.-Y., Zhao, N., \& Wang, S. (2019). Simultaneous adsorption of methyl orange and methylene blue from aqueous solution using amino functionalized $\mathrm{Zr}$-based MOFs. Microporous and Mesoporous Materials, 282, 179-187.

Ma, Y.-Z., Zheng, D.-F., Mo, Z.-Y., Dong, R.-J., \& Qiu, X.-Q. (2018). Magnetic lignin-based carbon nanoparticles and the adsorption for removal of methyl orange. Colloid and Surfaces A: Physiochemical and Engineering Aspects, 559, 226-234.

Marques-Fraga, T. J. M., Dos-Santos-Marques-Fraga, D. M., Da-Silva, T. C., Nascimento-Carvalho, M., \& Da-Motta-Sobrinho, M. A. (2018a). Adsorption of reactive dyes onto thermally treated waste from aluminum lamination. Water Practice \& Technology, 13(3), 629641.

Marques-Fraga, T. J., Nascimento-Carvalho, M., Marques-Fraga, D. M. D. S., Da-Silva, M. C. L., Ferreira, J. M., \& Da-Motta-Sobrinho, M. A. (2018b). Treated residue from aluminium lamination as adsorbent of toxic reactive dyes - a kinetic, equilibrium and thermodynamic study Environmental Technology, 41(6) 669-681.

Mashkoor, F., \& Nasar, A. (2020a). Magnetized Tectona grandis sawdust as a novel adsorbent: Preparation, characterization, and utilization for the removal of methylene blue from aqueous solution. Cellulose, $27,2613-2635$. 
Mashkoor, F., Nasar, A., (2020b). Magsorbents: Potential candidates in wastewater treatment technology-A review on the removal of methylene blue dye. Journal of Magnetism and Magnetic Materials, $500,166408$.

Meksi, N., \& Moussa, A. (2017). A review of progress in the ecological application of ionic liquids in textile processes. Journal of Cleaner Production, 161, 105-126.

Mirković, M. M., Lazarević-Pašti, T. D., Došen, A. M., Čebela, A. Ž., Rosić, A. A., Matović, B. Z., \& Babić, B. M. (2016). Adsorption of malathion on mesoporous monetite obtained by mechanochemical treatment of brushita. RSC Advances, 6, 12219-12225.

Mounia, L., Belkhirib, L., Bollingerc, J.-C., Bouzazad, A., Assadid, A., Tirrib, A., Dahmounee, F., Madanie, K., \& Reminie, H. (2018). Removal of Methylene Blue from aqueous solutions by adsorption on kaolin: Kinetic and equilibrium studies. Applied Clay Science, $153,38-45$.

Mudyawabikwa, B., Mungondori, H. H., Tichagwa, L., \& Katwire, D. M. (2017). Methylene blue removal using a low-cost activated carbon adsorbent from tobacco stems: Kinetic and equilibrium studies. Water Science and Technology, 75(10), 2390-2402.

Nayak, A. K., \& Pal, A. (2017). Green and efficient biosorptive removal of methylene blue by Abelmoschus esculentus seed: process optimization and multi-variate modeling. Journal of Environmental Management, 200, 145-159.

Nogueira-De-Paiva, T., Marques-Fraga, J., Sales, D. C. S., NascimientoCarvalho, N., \& Da-Motta-Sobrinho, A. (2018). Anomalocardia 
brasiliana shellfish shells as a novel and ecofriendly adsorbent of Nylosan Brilliant Blue acid dye. Water Science Technology, 78(7), 1576-1586.

Pai, S., Srinivas-Kini, M., \& Selvaraj, R. (2021). A review on adsorptive removal of dyes from wastewaterby hydroxyapatite nanocomposites. Environmental Science and Pollution Research, $28,11835-11849$.

Pakshiranja, K., Worku, A. N., Acheampong, M. A., Lubberding, H. J., \& Lens, P. N. L. (2013). Cr(III) and $\operatorname{Cr}(\mathrm{VI})$ removal from aqueous solutions by cheaply available fruit waste and algal biomass. Applied Biochemical Biotechnology, 170, 498-513.

Panneerselvam, K., Arul, K. T., Warrier, A. R., Asokan, K., \& Dong, C. -L. (February 2019). Rapid adsorption of industrial pollutants using metal ion doped hydroxyapatite. AIP Conference Proceedings, 2117, 020004. Chennai, India.

Pargoletti, E., Pifferi, V., Falciola, L., Facchinetti, G., Depaolini, A. R., Davoli, E., Marelli, M., \& Cappelletti, G. (2019). A detailed investigation of $\mathrm{MnO} 2$ nanorods to be grown onto activated carbon. High efficiency towards aqueous methyl orange adsorption/degradation. Applied Surface Science, 472, 118-126.

Pavithra, K. G., Kumar, P. S., Jaikumar, V., \& Rajan, P. S. (2019). Removal of colorants from wastewater: A review on sources and treatment strategies. Journal of Industrial and Engineering Chemistry, 75, 1-19.

Pessôa, T. S., De-Lima-Ferreira, L. E., Da-Silva, M. P., Pereira-Neto, L., M., Do-Nascimento, B. F., Marques Fraga, T., Freitas-Jaguaribe, E., 
Cavalcanti, J. V., \& Da-Motta-Sobrinho, M. A. (2019). Açaí waste beneficing by gasification process and its employment in the treatment of synthetic and raw textile wastewater. Journal of Cleaner Production, 240, 118047.

Qian, W.-C., Luo, X.-P., Wang, X., Guo, M., \& Li, B. (2018). Removal of methylene blue from aqueous solution by modified bamboo hydrochar. Ecotoxiucology and Environmental Safety, 157, 300306.

Rahman, A., Kishimoto, N., Urabe, T., \& Ikeda, K. (2017). Methylene blue removal by carbonized textile sludge-based adsorbent. Water Science and Technology, 76(11), 3126-3134.

Rahman, F. B. A., Akter, M., \& Abedin, M. Z. (2013). Dyes removal from textile wastewater using orange peels. International Journal of Scientific and Technology Research, 2(9), 47-50.

Raval, N. P., Shah, P. U., \& Shah, N. K. (2016). Adsorptive amputation of hazardous azo dye Congo red from wastewater: A critical review. Environmental Science and Pollution Research, 23, 14810-14853.

Schamel, M., Barrelet, J. E., Groll, J., \& Gbureck, U. (2017). In vitro ion adsorption and cytocompatibility of dicalcium phosphate ceramics. Biomaterials Research, 21(10), 1-9.

Shakoor, S., \& Nasar, A. (2018). Adsorptive treatment of hazardous methylene blue dye from artificially contaminated water using cucumis sativus peel waste as a low-cost adsorbent. Groundwater for Sustainable Development, 5, 152-159. 


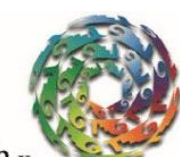

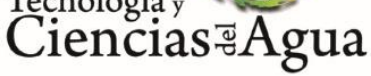

2021, Instituto Mexicano de Tecnología del Agua

Open Access bajo la licencia CC BY-NC-SA 4.0

(https://creativecommons.org/licenses/by-nc-sa/4.0/)

Shakoor, A., \& Nasar, A. (2016). Removal of methylene blue dye from artificially contaminated water using citrus limetta peel waste as a very low cost adsorbent. Journal of the Taiwan Institute of Chemical Engineers, 66, 154-163.

Shakoor, S., \& Nasar, A. (2017). Utilization of Punica granatum peel as an eco-friendly biosorbent for the removal of methylene blue dye from aqueous solution. Journal of Applied Biotechnology \& Bioengineering, 5(4), 242-249.

Sing, K. (1985). Reporting physisorption data for gas/solid systems with special reference to the determination of surface area and porosity. Chemistry Pure \& Applied, 57, 603-619.

Singh, K. K., Hasan, S. H., Talat, M., Singh, V. K., \& Gangwar, S. K. (2009). Removal of $\mathrm{Cr}$ (VI) from aqueous solutions using wheat bran. Chemical Engineering Journal, 151(1-3), 113-121.

Sivakumar, A., Murugesan, B., Loganathan, A., \& Sivakumar, P. (2014). Journal of the Taiwan Institute of Chemical Engineers, 45(5), 23002306.

Sopcak, T., Medvecky, L., Giretova, M., Stulajterova, R., Durisin, J., Girman, V., \& Faberova, M. (2016). A review on decolourisation of dyes by photodegradation using various bismuth catalysts. Materials Characterization, 117, 17-29.

Srilakshmi, C., \& Saraf, R. (2016). Ag-doped hydroxyapatite as efficient adsorbent for removal of Congo red dye from aqueous solution: Synthesis, kinetic and equilibrium adsorption isotherm analysis. Microporous and Mesoporous Materials, 219, 134-144. 
Sun, B., Yuan, Y., Li, H., Li, X., Zhang, C., Guo, F., Liu, X., Wang, K., \& Zhao, X. S. (2019). Waste-cellulose-derived porous carbon adsorbents for methyl orange removal. Chemical Engineering Journal, 371, 55-63.

Tabrizi, N. S., \& Yavari, M. (2015). Methylene blue removal by carbon nanotube-based aerogels. Chemical Engineering Research and Design, 94, 516-523.

Tamimi, F., Sheikh, Z., \& Barralet, J. (2012). Dicalcium phosphate cements: Brushite and monetite. Acta Biomaterialia, 8(2), 474-487.

Tara, N., Siddiqui, S., Rathi, I., Chaudhry, G., Inamuddin, S. A., \& Asiri, M. (2020). Nano-engineered adsorbent for the removal of dyes from water: A review. Current Analytical Chemistry, 16, 14-40.

Türk, S., Altınsoy, I., Çelebiefe G., Ipek, M., Özacar, M., C., \& Bindal. (2018). Biomimetric coating of monophasic brushite on Ti6Al4V in new m-5xSBF. Surface \& Coatings Technology, 351, 1-10.

Uddin, M. K., \& Baig, U. (2019). Synthesis of Co304 nanoparticles and their performance towards methyl orange dye removal: Characterisation, adsorption and response surface methodology. Journal of Cleaner Production, 211, 1141-1153.

Uddin, M., K., \& Nasar, A. (2020). Decolorization of basic dyes solution by utilizing fruit seed poder. KSCE Journal of Civil Engineering, $24(2), 345-355$.

Uyar, G., Kaygusuz, H., \& Erim, F. B. (2016). Methylene blue removal by alginate-clay quasi-cryogel beads. Reactive and Functional Polymers, 106, 1-7. 


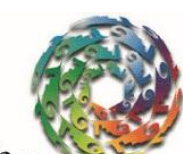

Cienciogias

Varaprasad, K., Nunez, D., Yallapu, M. M., Jayaramudu, T., Elgueta, E., \& Oyarzund, P. (2018). Nano-hydroxyapatite polymeric hydrogels for dye removal. RSC Advances, 8, 18118-18127.

Wang, N., Chen, J., Wang, J., Feng, J., \& Yan, W. (2019). Removal of methylene blue by Polyaniline/TiO2 hydrate: Adsorption kinetic, isotherm and mechanism studies. PowderTechnology, 347, 93-102.

Wang, X. S., Zhou, Y., Jiang, Y., \& Sun, C. (2008). The removal of basic dyes from aqueous solutions using agricultural by-products. Journal of Hazardous Materials, 157(2-3), 374-385.

Yang, C., Yu, X., Guan, L., Wang, J., Yang, X., Lin, M., You G., Tan, S., \& $\mathrm{Ge}$, M. (2019). Enhanced fluoride removal behaviour and mechanism by dicalcium phosphate from aqueous solution. Environmental Technology, 40(28), 3668-3677.

Yang, Y., \& Guan, C. (2018). Adsorption properties of activated carbon fiber forhighly effective removal of methyl orange dye. IOP Conference Series: Earth and Environmental Science, 208, 012005 (1-10).

Yaseen, A., \& Scholz, M. (2019). Textile dye wastewater characteristics and constituents of synthetic effluents: A critical review. Textile dye wastewater characteristics and constituents of synthetic effluents: a critical review. International Journal of Environmental Science and Technology, 16, 1193-1226.

Zhang, B., Wua, Y., \& Cha, L. (2019). Removal of methyl orange dye using activated biochar derived from pomelo peel wastes: performance, isotherm, and kinetic studies. Journal of Dispersion Science and Technology, 41(1), 125-136. 
Zhou, J. Z., Feng, L., Zhao, J., Liu, J., Liu, Q., Zhang, J., \& Qian, G. (2014). Efficient and controllable phosphate removal on hydrocalumite by multi-step treatment based on $\mathrm{pH}$-dependent precipitation. Chemical Engineering Journal, 185-186, 219-225.

Zhou, Y., Lu, J., Zhou, Y., \& Liu, Y. (2019). Recent advances for dyes removal using novel adsorbents: A review. Environmental Pollution, 252, 352-365.

Zong, Y., Li, K., Tian, R., Lin, Y., \& Lu, C. (2018). Highly dispersed layered double oxide hollow spheres with sufficient active sites for adsorption of methyl blue. Nanoscale, 10, 23191-23197. 